\title{
Photochemistry of Transition Metal Complexes Induced by Outer-Sphere Charge Transfer Excitation
}

\author{
Arnd Vogler and Horst Kunkely
}

Institut für Anorganische Chemie, Universität Regensburg,

Universitätsstraße 31, D-8400 Regensburg

\section{Table of Contents}

1 Introduction . . . . . . . . . . . . . . . . . . . . . 3

2 Theoretical Background . . . . . . . . . . . . . . . . . . . . . . 4

3 Spectroscopy. . . . . . . . . . . . . . . . . . . . . . . 6

3.1 Ion Pairs . . . . . . . . . . . . . . . . . . . . . . . . 7

3.1.1 Complex to Complex Charge Transfer . . . . . . . . . . . 7

3.1.2 Ion Pairs Consisting of a Complex and a Non-metallic

Counter Ion . . . . . . . . . . . . . . . . . . 13

3.2 Neutral Acceptors and/or Donors. . . . . . . . . . . . . . . 17

4 Photochemistry. . . . . . . . . . . . . . . . . . . . . . . . 18

4.1 Ion Pairs . . . . . . . . . . . . . . . . . . . . . . . . . 18

4.1.1 Complex to Complex Charge Transfer . . . . . . . . . . . 18

4.1.2 Ion Pairs Consisting of a Complex and a Non-metallic

Counter Ion . . . . . . . . . . . . . . . . 24

4.2 Neutral Acceptors and/or Donors. . . . . . . . . . . . . . 26

5 Outlook and Conclusion . . . . . . . . . . . . . . . . . . . . . . . 27

6 References. . . . . . . . . . . . . . . . . . 27

The intermolecular (outer sphere, OS) interaction of a reducing and an oxidizing metal complex generates a new optical transition involving charge transfer (CT) from the electron donor to the acceptor. OS CT transitions are classified according to the redox site (metal or ligand). Generally, the interaction between donor and acceptor is facilitated by ion pairs consisting of an oxidizing complex cation and a reducing complex anion. There are also ion pairs which are composed of a metal complex and an organic counter ion as electron donor or acceptor. In addition, the review 
includes examples of OS CT interaction which do not involve ion pairs at all. - A short introduction into the theory is followed by the discussion of the spectroscopy of OS CT of transition metal complexes. Finally, photoreactions induced by OS CT transitions are reviewed. The optical transfer is frequently followed by a rapid back electron transfer which regenerates the starting complexes. In many cases the primary products are kinetically labile and substitution reactions compete successfully with back electron transfer. As a result stable redox products may be formed. As an alternative, the substitution can be followed by back electron transfer. Product formation appears then as a substitution of the starting complexes. The various possibilities are illustrated by appropriate examples. 


\section{Introduction}

The exchange of an electron between two molecules may be considered to be the most fundamental and important chemical reaction. Such a redox process can occur thermally or photochemically. Intermolecular light-induced electron transfer involving transition metal complexes has been extensively studied during the last 15 years [1-8]. This interest was stimulated, at least partially, by attempts to develop an artificial photosynthesis for the conversion and chemical storage of solar energy [9-11]. It is well known that natural photosynthesis requires a light-induced electron transfer as the basic process.

Intermolecular photochemical electron transfer takes place by two different mechanisms. First, an electronically excited molecule may undergo an electron exchange with another molecule in its ground state. Secondly, a direct optical electron transfer can be achieved if the electron donor and acceptor are electronically coupled by a close contact. The majority of studies involving coordination compounds has been devoted to excited state electron transfer [1-8] while much less information is available on the second mechanism [6-8, 12-15] which is the subject of the present review.

Intermolecular and outer sphere (OS) electron transfer are frequently used as synonymous expressions. Generally, this is justified. However, in some cases both terms are not equivalent. While an intermolecular electron transfer is indeed always of the OS type, an OS electron transfer is not necessarily an intermolecular process. For example, in the complex $\left[\left(\mathrm{NH}_{3}\right)_{5} \mathrm{Ru}^{\mathrm{II}} \mathrm{SC}_{6} \mathrm{H}_{12} \mathrm{SRu}^{\mathrm{III}}-\right.$ $\left.\left(\mathrm{NH}_{3}\right)_{5}\right]^{5+}$ an optical electron transfer from $\mathrm{Ru}^{\mathrm{II}}$ to $\mathrm{Ru}^{\mathrm{III}}$ takes place [16]. This intramolecular process occurs by an OS mechanism since the electronic coupling between both metals is not mediated by connecting atoms. In distinction to an inner sphere (IS) transfer the electronic interaction does not take place via chemical bonds but rather through space. However, for most practical purposes intermolecular and OS electron transfer describe equivalent processes.

While the electronic coupling by an OS interaction is generally rather weak it may become quite strong if it is of the IS type although there is also a number of remarkable exceptions [17]. An IS mechanism is always in operation when the donor and acceptor site are connected by a direct bond without an intervening atom. Before we enter the discussion of light-induced OS electron transfer it is appropriate to mention briefly the typical optical IS charge transfer (CT) transitions of metal complexes which are classified according to the redox sites [18].

Ligand to metal CT (LMCT) absorption bands appear at long wavelength if the ligand is reducing and the metal oxidizing. $\mathrm{Fe}$ (III) and $\mathrm{Co}$ (III) complexes are well-documented examples. LMCT bands cause the colors of $\mathrm{d}^{0}$ oxometallates such as $\mathrm{CrO}_{4}^{2-}$ (yellow) and $\mathrm{MnO}_{4}^{-}$(violet).

Metal to ligand (MLCT) is another classical optical transition of metal complexes. MLCT absorptions are observed at long wavelength if the metal is reducing and a ligand provides low-energy empty orbitals. Complexes such as $\left[\mathrm{Fe}(\mathrm{CN})_{6}\right]^{4-}$ and $\left[\mathrm{Ru}(\text { bipy })_{3}\right]^{2+}$ (bipy $=2,2^{\prime}$-bipyridyl) are typical cases. In addition, organometallics which contain a metal in a low oxidation state and 
$\pi$-accepting ligands such as an olefin or an aromatic molecule are characterized by low-energy MLCT bands [18, 19].

Metal to metal CT (MMCT) bands occur only in the absorption spectra of binuclear (or polynuclear) complexes which contain a reducing and an oxidizing metal. Two cases can be distinguished. Both metals are either bridged by a suitable ligand $\left(\mathrm{M}_{\mathrm{red}}-\mathrm{L}-\mathrm{M}_{\mathrm{ox}}\right)[2,12,17-24]$ or connected by a direct, but polar metal-metal bond $\left(\mathrm{M}_{\mathrm{red}}-\mathrm{M}_{\mathrm{ox}}\right)$. The binuclear complexes $\left[\left(\mathrm{NH}_{3}\right)_{5} \mathrm{Co}^{\mathrm{III}}\right.$ $\left.\mathrm{NCRu}{ }^{\mathrm{II}}(\mathrm{CN})_{5}\right]^{-}[12,17]$ and $\left[\mathrm{Ph}_{3} \mathrm{PAu}^{\mathrm{I}}-\mathrm{Co}^{-\mathrm{I}}(\mathrm{CO})_{4}\right][25]$ are typical compounds which show low-energy MMCT bands.

Ligand to ligand CT (LLCT) absorptions were identified only recently [26]. These bands appear if one ligand is reducing and another oxidizing $\left(\mathrm{L}_{\text {red }}-\mathrm{M}-\mathrm{L}_{\text {ox }}\right)$. In simple cases $\mathrm{L}_{\text {red }}$ may be a halide, thiolate, aryl or alkyl group while polypyridyls such as bipy serve as oxidizing ligands. A specific form of $\mathrm{L}_{\mathrm{red}}-\mathrm{M}-\mathrm{L}_{\mathrm{ox}}$ complexes which display LLCT absorptions are ligand-based mixed-valence complexes. These compounds contain the same ligand in an oxidized and reduced form.

Let us now return to optical OS CT of metal complexes. The following discussion is presented in several sections. First, a brief description of the theoretical background is given. Secondly, the spectroscopy is discussed. Finally, the photochemistry induced by optical OS CT of metal complexes is treated.

\section{Theoretical Background}

An optical OS CT transition may occur if a reducing and an oxidizing molecule or ion are in close contact which provides some orbital overlap of the donor and acceptor. This close contact is frequently facilitated by the electrostatic attraction within an ion pair. But also neutral molecules may be close enough under suitable conditions, particularly at high concentrations or in the solid state. The electronic interaction between an electron donor and acceptor and the resulting optical CT transition can be understood on the basis of a theory advanced by N. S. Hush [21, 22, 24, 27, 28]. Although this theory was first developed for donating and accepting metal centers it can be applied to any other redox site as well. The Hush model in its simplest form requires a weak electronic interaction between donor and acceptor. This is certainly valid for the majority of the OS systems discussed in this article since donor and acceptor are not coupled by chemical bonds. The overlap of the orbitals involved in the OS CT transition is assumed to be rather small. The electronic spectrum of the donor/ acceptor pair consists then of the superimposed spectra of the single components. In addition, a new absorption band appears which belongs to the optical CT transition from the donor (D) to the acceptor (A).

The energy of this OS CT transition $\left(\mathrm{E}_{\mathrm{CT}}\right)$ depends on the potential difference $\Delta \mathrm{E}$ between the redox couples $\mathrm{D} / \mathrm{D}^{+}$and $\mathrm{A} / \mathrm{A}^{-}$and on the reorganizational energy $\chi$ (Fig. 1).

$$
\mathrm{E}_{\mathrm{CT}}=\Delta \mathrm{E}+\chi
$$




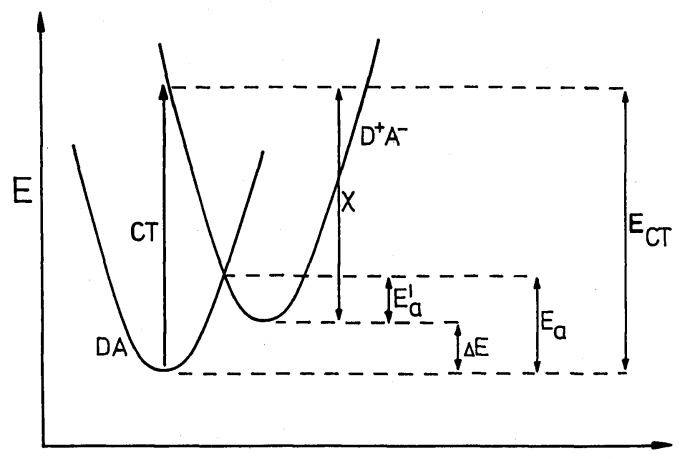

nuclear coordinates
Fig. 1. Potential energy diagram for electron transfer from a donor (D) to an acceptor (A)

The parameter $\chi$ consists of an outer and an inner part.

$$
\chi=\chi_{0}+\chi_{i}
$$

The inner contribution $\chi_{i}$ is a fraction of the Franck-Condon CT transition as shown in Fig. 1. It depends on the structural distortion which accompanies electron transfer. In the case of a metal complex this structural reorganization which may be associated with changes of the metal-ligand bond length varies with the oxidation state of the metal. Frequently, reduction is associated with an extension of the metal-ligand distance when an antibonding orbital is populated.

The optical CT as a Franck-Condon transition terminates in a vibrationally excited state of the redox isomer $\mathrm{D}^{+} \mathrm{A}^{-}$before it relaxes. The electron transfer can not only be achieved by light absorption but also as a thermal process which requires the activation energy $\mathrm{E}_{\text {th }}$ to reach the crossing point of both potential curves (Fig. 1). When the redox isomer has relaxed to its vibrationally ground state it may undergo a thermal back electron transfer by overcoming the activation energy $\mathrm{E}_{\mathrm{a}}^{\prime}=\mathrm{E}_{\text {th }}-\Delta \mathrm{E}$.

While $\chi_{i}$ is an intrinsic property of the redox pair AD the outer part $\chi_{0}$ depends on the reorganization of the solvent environment.

$$
\chi_{0}=e^{2}\left(\frac{1}{2 a_{1}}+\frac{1}{2 a_{1}}-\frac{1}{d}\right)\left(\frac{1}{n^{2}}-\frac{1}{D}\right)
$$

The parameters $a_{1}$ and $a_{2}$ are the radii of the donor and acceptor assuming spherical structures. This assumption seems to be justified for tetrahedral or octahedral complexes. However, in the case of planar electron donor or acceptors such a simple picture certainly does not apply. A further parameter is the distance $d$ between $D$ and $A$ with $d=a_{1}+a_{2}$ as the closest possible approach. The polarity of solvent contributes also to $\chi_{0}$. This polarity is represented by the term $1 / \mathrm{n}^{2}-1 / \mathrm{D}$ and determined by the refractive index $n$ and the static dielectric constant $D$ of the solvent. It follows that with an increasing solvent polarity and an increasing 
distance between donor and acceptor also the term $\chi_{0}$ and finally the energy of the optical CT transition become larger [29].

The outer contribution $\chi_{0}$ to the overall reorganizational energy introduces a serious complication to the evaluation of an optical OS CT. A change of the solvent does not only effect $\chi_{0}$ by a variation of the solvent polarity. It can also affect the mutual orientation of donor and acceptor, particularly the distance d. For example, when the donor and acceptor are ions an increasing solvent polarity may increase also the distance $d$ by an extension of the solvation shell of the ions. An empirical correlation which apparently takes care of these complications has been recently introduced to evaluate and predict the energy of optical OS CT transitions. This increment system developed by Hennig, Bendix, and Billing works rather well $[15,30,31]$. If follows that the solvent polarity and the distance $d$ seem to vary in a predictable fashion.

Light absorption into the OS CT band is a photoredox process by definition. Generally, the generation of $\mathrm{D}^{+} \mathrm{A}^{-}$is followed by a rapid back electron transfer which requires a rather small activation energy $E_{a}^{\prime}$ (Fig. 1). As a consequence a permanent chemical change does not take place. An irreversible formation of stable photoproducts can be only achieved if the redox isomer $\mathrm{D}^{+} \mathrm{A}^{-}$ is able to undergo some further structural rearrangements. These secondary processes must be fast enough to compete with back electron transfer. For example, photoactivity is expected if $\left[\mathrm{Co}\left(\mathrm{NH}_{3}\right)_{6}\right]^{3+}$ is the electron acceptor. Upon reduction $\left[\mathrm{Co}\left(\mathrm{NH}_{3}\right)_{6}\right]^{2+}$ is generated. It is kinetically very labile and undergoes a rapid decomposition in aqueous solution [32]. When the productforming step is not very fast back electron transfer is certainly favored but a cage escape of the primary redox pair $\mathrm{D}^{+} \mathrm{A}^{-}$may facilitate a secondary reaction.

\section{Spectroscopy}

In analogy to IS CT transitions [18] optical OS CT can be classified according to the predominant localization of donor and acceptor orbitals at the ligand or metal. In suitable cases OS MLCT, OS LMCT, OS LLCT, and OS MMCT transitions will then be observed. In addition, the donor or acceptor may not be a metal complex at all. The corresponding OS CT transitions are now of the complex to acceptor and donor to complex type. Again, donor and acceptor orbitals can be located at the metal or ligand.

The charge of the donor and acceptor is used as a further classification of OS CT. As discussed below the majority of OS CT is observed for ion pairs which consist of an accepting cation and a donating anion. It is quite understandable that the electronic interaction between donor and acceptor is facilitated by electrostatic attraction in the ion pairs. In systems which do not consist of ion pairs high concentrations of at least one redox partner is required. OS CT transitions of this type can be identified either in the solid state or if the donor or acceptor is the solvent. The latter transition is well known as CT to solvent (CTTS) transition $[8,19,33]$. The reverse process, namely optical CT from the solvent, has not yet been observed to our knowledge. 


\subsection{Ion Pairs}

The intensity of an OS CT absorption of an ion pair is influenced by the solvent in various ways. More polar solvents will favor the-dissociation of the ion pair. In less polar solvents the solvation of ions and thus the distance between donor and acceptor are much smaller. The orbital overlap and consequently the intensity of the OS CT bands of these contact ion pairs are expected to be much larger than those of solvent-separated or dissociated ion pairs. It follows that the detection of an OS CT band of ion pairs is often facilitated by the use of nonpolar solvents. Unfortunately, this choice is frequently limited by the low solubilities of the ion pairs in solvents of low polarity.

Occasionally it is questionable if observed CT absorptions are really due to ion pairs. In some cases they rather belong to ligand-bridged bi- or polynuclear complexes and are of IS CT type which are not discussed in this review. Caution must be applied if one complex ion provides ligands which are potentially bridging (e.g. $\left.\mathrm{CN}^{-}\right)$and the counter ion is kinetically not inert (e.g. $\left[\mathrm{Fe}\left(\mathrm{H}_{2} \mathrm{O}\right)_{6}\right]^{3+}$ or $\left.\left[\mathrm{Cu}\left(\mathrm{H}_{2} \mathrm{O}\right)_{6}\right]^{2+}\right)$. Under these conditions it is likely that the donor and acceptor site are bridged by a ligand which mediates as IS CT interaction.

Another interesting but unresolved problem concerns the sign of the charge of the donor and acceptor ion. To our knowledge all studies have only dealt with ion pairs which consist of anionic donors and cationic acceptors but never with reversed ion pairs (cationic donors and anionic acceptors). This situation may be accidental since there does not seem to be any explanation of this observation. Ion pairs such as $\mathrm{Ag}^{+} \mathrm{CrO}_{4}^{2-}$ or $\mathrm{Ag}^{+} \mathrm{MnO}_{4}^{-}$which display $\mathrm{Ag}^{+}$to $\mathrm{Cr}^{\mathrm{VI}}$ or $\mathrm{Mn}^{\mathrm{VII}}$ MMCT bands could be exceptions [34].

However, these CT bands were only detected for the salts in the solid state. Again, it is not sure if these salts can be really considered as ion pairs or if donor and acceptor interact via bridging ligands (e.g. $\mathrm{Ag}-\mathrm{O}-\mathrm{Cr}$ ).

\subsubsection{Complex to Complex Charge Transfer}

\section{MLCT}

Aqueous solutions of the ion pairs $\left[\mathrm{Rh}(\text { bipy })_{3}\right]^{3+}\left[\mathrm{M}(\mathrm{CN})_{6}\right]^{4-}$ with $\mathrm{M}=\mathrm{Fe}, \mathrm{Ru}$, and Os display $\mathrm{M}^{\mathrm{II}}$ to bipy OS MLCT absorptions at $\lambda_{\max }=480 \mathrm{~nm}(\varepsilon=61)$ for $\mathrm{M}=\mathrm{Fe}, 400 \mathrm{~nm}$ (155) for Os, and $379 \mathrm{~nm}$ (110) for Ru [35]. As expected the OS CT bands shift to lower energies in the order of increasing reducing strength of $\left[\mathrm{M}(\mathrm{CN})_{6}\right]^{4-}\left(\mathrm{E}_{1 / 2}=0.19 \mathrm{~V}\right.$ for Fe, $0.40 \mathrm{~V}$ for Os and $0.70 \mathrm{~V}$ vs SCE for $\left.\mathrm{Ru}\right)$. The reorganizational energy which is associated with electron transfer was estimated to be $\sim 15000 \mathrm{~cm}^{-1}$ for all three ion pairs.

\section{LMCT}

The electronic spectrum of the aqueous ion pair $\left[\mathrm{Ru}\left(\mathrm{NH}_{3}\right)_{6}\right]^{3+}\left[\mathrm{Rh}(\mathrm{CN})_{6}\right]^{3-}$ contains a new absorption band at $\lambda_{\max }=297 \mathrm{~nm}(\varepsilon=29)$ which appears well resolved in the difference spectrum [36]. This band was assigned to an OS LMCT transition from cyanide coordinated at $\mathrm{Rh}^{\mathrm{III}}$ to $\mathrm{Ru}^{\mathrm{III}}$ of the counter ion. The 
Table 1. Optical OS CT (metal to metal) Transitions of ion pairs

\begin{tabular}{|c|c|c|c|c|}
\hline Acceptor & Donor & $\begin{array}{l}\text { Abs. } \\
\lambda_{\text {max }} / \mathrm{nm}\end{array}$ & Solvent & Ref] \\
\hline$\left[\mathrm{Co}\left(\mathrm{NH}_{3}\right)_{6}{ }^{3+}\right.$ & {$\left[\mathrm{Fe}(\mathrm{CN})_{6}\right]^{4-}$} & 440 & $\mathrm{H}_{2} \mathrm{O}$ & {$[40]$} \\
\hline$\left[\mathrm{Co}(\text { ethylenediamine })_{3}\right]^{3+}$ & {$\left[\mathrm{Fe}(\mathrm{CN})_{6}\right]^{4-}$} & 430 & $\mathrm{H}_{2}^{2} \mathrm{O}$ & {$[40]$} \\
\hline$\left[\mathrm{Co}\left(\mathrm{NH}_{3}\right)_{6}\right]^{3+}$ & {$\left[\mathrm{Ru}(\mathrm{CN})_{6}\right]^{4-}$} & 360 & DMSO & [41] \\
\hline$\left[\mathrm{Co}\left(\mathrm{NH}_{3}\right)_{6}\right]^{3+}$ & {$\left[\mathrm{Ru}(\mathrm{CN})_{6}\right]^{4-}$} & 344 & $\mathrm{H}_{2} \mathrm{O}$ & {$[42]$} \\
\hline$\left[\mathrm{Co}(\text { ethylenediamine })_{3}\right]^{3+}$ & {$\left[\mathrm{Ru}(\mathrm{CN})_{6}\right]^{4-}$} & 351 & $\mathrm{H}_{2}^{2} \mathrm{O}$ & {$[42]$} \\
\hline$\left[\mathrm{Co}(1,2 \text {-diaminopropane })_{3}\right]^{3+}$ & {$\left[\mathrm{Ru}(\mathrm{CN})_{6}\right]^{4-}$} & 353 & $\mathrm{H}_{2}^{2} \mathrm{O}$ & {$[42]$} \\
\hline$\left[\mathrm{Co}(1,2 \text {-cyclohexanediamine })_{3}\right]^{3+}$ & {$\left[\mathrm{Ru}(\mathrm{CN})_{6}\right]^{4-}$} & 359 & $\mathrm{H}_{2}^{2} \mathrm{O}$ & {$[42]$} \\
\hline$[\mathrm{Co}(\text { sepulchrate })]^{3+}$ & {$\left[\mathrm{Ru}(\mathrm{CN})_{6}\right]^{4-}$} & 374 & $\mathrm{H}_{2}^{2} \mathrm{O}$ & {$[42]$} \\
\hline$\left[\mathrm{Ru}\left(\mathrm{NH}_{3}\right)_{5}(4 \text {-bromopyridine })\right]^{3+}$ & {$\left[\mathrm{Fe}(\mathrm{CN})_{6}\right]^{4-}$} & 932 & $\mathrm{H}_{2}^{2} \mathrm{O}$ & [46] \\
\hline$\left[\mathrm{Ru}\left(\mathrm{NH}_{3}\right)_{5}(4 \text {-chloropyridine })\right]^{3+}$ & {$\left[\mathrm{Fe}(\mathrm{CN})_{6}\right]^{4-}$} & 940 & $\mathrm{H}_{2}^{2} \mathrm{O}$ & {$[46]$} \\
\hline$\left[\mathrm{Ru}\left(\mathrm{NH}_{3}\right)_{5}(\text { pyridine })\right]^{3+}$ & {$\left[\mathrm{Fe}(\mathrm{CN})_{6}\right]^{4-}$} & 910 & $\mathrm{H}_{2}^{2} \mathrm{O}$ & {$[44,46]$} \\
\hline$\left[\mathrm{Ru}\left(\mathrm{NH}_{3}\right)_{5}(4 \text {-methylpyridine })\right]^{3+}$ & {$\left[\mathrm{Fe}(\mathrm{CN})_{6}\right]^{4-}$} & 898 & $\mathrm{H}_{2}^{2} \mathrm{O}$ & [46] \\
\hline$\left[\mathrm{Ru}\left(\mathrm{NH}_{3}\right)_{5}(4-\mathrm{t} \text {-butylpyridine }]^{3+}\right.$ & {$\left[\mathrm{Fe}(\mathrm{CN})_{6}\right]^{4-}$} & 894 & $\mathrm{H}_{2}^{2} \mathrm{O}$ & {$[46]$} \\
\hline$\left[\mathrm{Ru}\left(\mathrm{NH}_{3}\right)_{5}(\text { pyrazole })\right]^{3+}$ & {$\left[\mathrm{Fe}(\mathrm{CN})_{6}\right]^{4-}$} & 864 & $\mathrm{H}_{2}^{2} \mathrm{O}$ & [46] \\
\hline$\left[\mathrm{Ru}\left(\mathrm{NH}_{3}\right)_{5}(2,5 \text {-dimethylpyrazole })\right]^{3+}$ & {$\left[\mathrm{Fe}(\mathrm{CN})_{6}\right]^{4-}$} & 810 & $\mathrm{H}_{2} \mathrm{O}$ & [46] \\
\hline$\left[\mathrm{Ru}\left(\mathrm{NH}_{3}\right)_{5}(\text { imidazole })\right]^{3+}$ & {$\left[\mathrm{Fe}(\mathrm{CN})_{6}\right]^{4-}$} & 788 & $\mathrm{H}_{2}^{2} \mathrm{O}$ & [46] \\
\hline$\left[\mathrm{Ru}\left(\mathrm{NH}_{3}\right)_{6}\right]^{3+}$ & {$\left[\mathrm{Fe}(\mathrm{CN})_{6}\right]^{4-}$} & 737 & Nujol & [44] \\
\hline$\left[\mathrm{Ru}\left(\mathrm{NH}_{3}\right)_{6}\right]^{3+}$ & {$\left[\mathrm{Fe}(\mathrm{CN})_{6}\right]^{4-}$} & 714 & $\mathrm{H}_{2} \mathrm{O}$ & [45] \\
\hline$\left[\mathrm{Ru}\left(\mathrm{NH}_{3}\right)_{6}\right]^{3+}$ & {$\left[\mathrm{Fe}(\mathrm{CN})_{5} \mathrm{CO}\right]^{3-}$} & 450 & $\mathrm{H}_{2}^{2} \mathrm{O}$ & {$[45]$} \\
\hline$\left[\mathrm{Ru}\left(\mathrm{NH}_{3}\right)_{6}\right]^{3+}$ & {$\left[\mathrm{Fe}(\mathrm{CN})_{5}(\text { dimethylsulfoxide })\right]^{3-}$} & 558 & $\mathrm{H}_{2} \mathrm{O}$ & {$[45]$} \\
\hline$\left[\mathrm{Ru}\left(\mathrm{NH}_{3}\right)_{6}\right]^{3+}$ & {$\left[\mathrm{Fe}(\mathrm{CN})_{5}(\text { pyrazine })\right]^{3-}$} & 667 & $\mathrm{H}_{2}^{2} \mathrm{O}$ & {$[45]$} \\
\hline$\left[\mathrm{Ru}\left(\mathrm{NH}_{3}\right)_{6}\right]^{3+}$ & {$\left[\mathrm{Fe}(\mathrm{CN})_{5}(\text { pyridine })\right]^{3-}$} & 725 & $\mathrm{H}_{2}^{2} \mathrm{O}$ & [45] \\
\hline$\left[\mathrm{Ru}\left(\mathrm{NH}_{3}\right)_{6}\right]^{3+}$ & {$\left[\mathrm{Fe}(\mathrm{N})_{5}(\text { imidazole })\right]^{3-}$} & 741 & $\mathrm{H}_{2}^{2} \mathrm{O}$ & {$[45]$} \\
\hline$\left[\mathrm{Ru}\left(\mathrm{NH}_{3}\right)_{6}\right]^{3+}$ & {$\left[\mathrm{Ru}(\mathrm{CN})_{6}\right]^{4-}$} & 541 & Nujol & [44] \\
\hline$\left[\mathrm{Ru}\left(\mathrm{NH}_{3}\right)_{6}\right]^{3+} \cdot$ & {$\left[\mathrm{Ru}(\mathrm{CN})_{6}\right]^{4-}$} & 549 & $\mathrm{H}_{2} \mathrm{O}$ & [45] \\
\hline$\left[\mathrm{Ru}\left(\mathrm{NH}_{3}\right)_{5}(3,5 \text {-dimethylpyrazine })\right]^{3+}$ & {$\left[\mathrm{Ru}(\mathrm{CN})_{6}\right]^{4-}$} & 700 & $\mathrm{H}_{2}^{2} \mathrm{O}$ & {$[46]$} \\
\hline$\left[\mathrm{Ru}\left(\mathrm{NH}_{3}\right)_{5}(3,5 \text {-dichloropyridine })\right]^{3+}$ & {$\left[\mathrm{Ru}(\mathrm{CN})_{6}\right]^{4-}$} & 675 & $\mathrm{H}_{2}^{2} \mathrm{O}$ & [46] \\
\hline$\left[\mathrm{Ru}\left(\mathrm{NH}_{3}\right)_{5}(\text {-chloropyridine })\right]^{3+}$ & {$\left[\mathrm{Ru}(\mathrm{CN})_{6}\right]^{4-}$} & 665 & $\mathrm{H}_{2}^{2} \mathrm{O}$ & {$[46]$} \\
\hline$\left[\mathrm{Ru}\left(\mathrm{NH}_{3}\right)_{5} \text { (4-bromopyridine) }\right]^{3+}$ & {$\left[\mathrm{Ru}(\mathrm{CN})_{6}\right]^{4-}$} & 653 & $\mathrm{H}_{2}^{2} \mathrm{O}$ & [46] \\
\hline$\left[\mathrm{Ru}\left(\mathrm{NH}_{3}\right)_{5}(4 \text {-chloropyridine })\right]^{3+}$ & {$\left[\mathrm{Ru}(\mathrm{CN})_{6}\right]^{4-}$} & 656 & $\mathrm{H}_{2}^{2} \mathrm{O}$ & {$[46]$} \\
\hline
\end{tabular}

[Co(sepulchrate $)]^{3+}$

Ru( $\left.\mathrm{NH}_{3}\right)_{5}$ (4-bromopyridine)

$\left[\mathrm{Ru}\left(\mathrm{NH}_{3}\right)_{5} \text { (pyridine) }\right]^{3}$

$\left[\mathrm{Ru}\left(\mathrm{NH}_{3}\right)_{5}(4 \text {-methylpyridine })\right]^{3+}$

$\left[\mathrm{Ru}\left(\mathrm{NH}_{3}\right)_{5} \text { (imidazole) }\right]^{3+}$

$\left[\mathrm{Ru}\left(\mathrm{NH}_{3}\right)_{6}\right]^{3+}$

$\left.\mathrm{NH}_{3}\right)_{6}$

$\left.\mathrm{Ru}\left(\mathrm{NH}_{3}\right)_{6}\right]^{3+}$

$\left.\mathrm{Ru}\left(\mathrm{NH}_{3}\right)_{6}\right]^{3+}$

$\left[\mathrm{Ru}\left(\mathrm{NH}_{3}\right)_{6}\right]^{3}$

$\left[\mathrm{Ru}\left(\mathrm{NH}_{3}\right)_{6}\right]^{3}$

$\left[\mathrm{Ru}\left(\mathrm{NH}_{3}\right)_{5} \text { (3,5-dimethylpyrazine) }\right]^{3}$

(

$\left[\mathrm{Ru}\left(\mathrm{NH}_{3}\right)_{5} \text { (4-bromopyridine) }\right]^{3}$

$\left[\mathrm{Ru}\left(\mathrm{NH}_{3}\right)_{5} \text { (4-chloropyridine) }\right]^{3+}$ 


\begin{tabular}{|c|c|c|c|c|}
\hline$\left[\mathrm{Ru}\left(\mathrm{NH}_{3}\right)_{5}(\text { pyridine })\right]^{3+}$ & {$\left[\mathrm{Ru}(\mathrm{CN})_{6}\right]^{4-}$} & 643 & $\mathrm{H}_{2} \mathrm{O}$ & {$[46]$} \\
\hline$\left[\mathrm{Ru}\left(\mathrm{NH}_{3}\right)_{5}(4 \text {-methylpyridine })\right]^{3+}$ & {$\left[\mathrm{Ru}(\mathrm{CN})_{6}\right]^{4-}$} & 627 & $\mathrm{H}_{2}^{2} \mathrm{O}$ & [46] \\
\hline$\left[\mathrm{Ru}\left(\mathrm{NH}_{3}\right)_{5} \mathrm{Cl}\right]^{2+}$ & {$\left[\mathrm{Ru}(\mathrm{CN})_{6}\right]^{4-}$} & 510 & $\mathrm{H}_{2}^{2} \mathrm{O}$ & {$[47]$} \\
\hline$\left[\mathrm{Ru}\left(\mathrm{NH}_{3}\right)_{5}(3,5 \text {-dimethylpyrazine })\right]^{3+}$ & {$\left[\mathrm{Os}(\mathrm{CN})_{6}\right]^{4-}$} & 716 & $\mathrm{H}_{2}^{2} \mathrm{O}$ & {$[46]$} \\
\hline$\left[\mathrm{Ru}\left(\mathrm{NH}_{3}\right)_{5}(3,5 \text {-dichlorpyridine })\right]^{3+}$ & {$\left[\mathrm{Os}(\mathrm{CN})_{6}\right]^{4-}$} & 700 & $\mathrm{H}_{2}^{2} \mathrm{O}$ & [46] \\
\hline$\left[\mathrm{Ru}\left(\mathrm{NH}_{3}\right)_{5}(4 \text {-bromopyridine })\right]^{3+}$ & {$\left[\mathrm{Os}(\mathrm{CN})_{6}\right]^{4-}$} & 670 & $\mathrm{H}_{2}^{2} \mathrm{O}$ & [46] \\
\hline$\left[\mathrm{Ru}\left(\mathrm{NH}_{3}\right)_{5}(3 \text {-chlorpyridine })\right]^{3+}$ & {$\left[\mathrm{Os}(\mathrm{CN})_{6}\right]^{4-}$} & 668 & $\mathrm{H}_{2}^{2} \mathrm{O}$ & {$[46]$} \\
\hline$\left[\mathrm{Ru}\left(\mathrm{NH}_{3}\right)_{5}(\text { pyridine })\right]^{3+}$ & {$\left[\mathrm{Os}(\mathrm{CN})_{6}\right]^{4-}$} & 658 & $\mathrm{H}_{2}^{2} \mathrm{O}$ & {$[46]$} \\
\hline$\left[\mathrm{Ru}\left(\mathrm{NH}_{3}\right)_{5}(4-\mathrm{t} \text {.-butylpyridine })\right]^{3+}$ & {$\left[\mathrm{Os}(\mathrm{CN})_{6}\right]^{4-}$} & 625 & $\mathrm{H}_{2}^{2} \mathrm{O}$ & [46] \\
\hline$\left[\mathrm{Ru}\left(\mathrm{NH}_{3}\right)_{5}(4-\text {-methylpyridine })\right]^{3+}$ & {$\left[\mathrm{Os}(\mathrm{CN})_{6}\right]^{4-}$} & 626 & $\mathrm{H}_{2}^{2} \mathrm{O}$ & [46] \\
\hline$\left[\mathrm{Os}\left(\mathrm{NH}_{3}\right)_{5} \mathrm{Cl}\right]^{2+}$ & {$\left[\mathrm{Fe}(\mathrm{CN})_{6}\right]^{4-}$} & 438 & $\mathrm{H}_{2}^{2} \mathrm{O}$ & {$[12,42]$} \\
\hline$\left[\mathrm{Os}\left(\mathrm{NH}_{3}\right)_{5} \mathrm{Cl}\right]^{2+}$ & {$\left[\mathrm{Ru}(\mathrm{CN})_{6}\right]^{4-}$} & 372 & $\mathrm{H}_{2}^{2} \mathrm{O}$ & {$[12,42]$} \\
\hline$\left[\mathrm{Os}\left(\mathrm{NH}_{3}\right)_{5} \mathrm{Cl}\right]^{2+}$ & {$\left[\mathrm{Os}(\mathrm{CN})_{6}\right]^{4-}$} & 388 & $\mathrm{H}_{2} \mathrm{O}$ & {$[12,42]$} \\
\hline$[\mathrm{Eu}(2.2 .1 \text { cryptand })]^{3+}$ & {$\left[\mathrm{Fe}(\mathrm{CN})_{6}\right]^{4-}$} & 530 & $\mathrm{H}_{2}^{2} \mathrm{O}$ & {$[48,49]$} \\
\hline$[\mathrm{Eu}(2.2 .1 \text { cryptand })]^{3+}$ & {$\left[\mathrm{Ru}(\mathrm{CN})_{6}\right]^{4-}$} & 434 & $\mathrm{H}_{2} \mathrm{O}$ & {$[48,49]$} \\
\hline$[\mathrm{Eu}(2.2 .1 \text { cryptand })]^{3+}$ & {$\left[\mathrm{Os}(\mathrm{CN})_{6}\right]^{4-}$} & 450 & $\mathrm{H}_{2} \mathrm{O}$ & {$[48,49]$} \\
\hline$\left[\mathrm{Pt}\left(\mathrm{NH}_{3}\right)_{5} \mathrm{Cl}\right]^{3+}$ & {$\left[\mathrm{Fe}(\mathrm{CN})_{6}\right]^{4-}$} & 418 & $\mathrm{H}_{2}^{2} \mathrm{O}$ & [50] \\
\hline$\left[\mathrm{Pt}\left(\mathrm{NH}_{3}\right)_{5} \mathrm{Cl}\right]^{3+}$ & {$\left[\mathrm{Ru}(\mathrm{CN})_{6}\right]^{4-}$} & 332 & $\mathrm{H}_{2}^{2} \mathrm{O}$ & {$[50]$} \\
\hline$\left[\mathrm{Pt}\left(\mathrm{NH}_{3}\right)_{5} \mathrm{Cl}\right]^{3+}$ & {$\left[\mathrm{Os}(\mathrm{CN})_{6}\right]^{4-}$} & 353 & $\mathrm{H}_{2}^{2} \mathrm{O}$ & {$[50]$} \\
\hline$\left[\mathrm{Pt}\left(\mathrm{NH}_{3}\right)_{5} \mathrm{Cl}\right]^{3+}$ & {$\left[\mathrm{Pt}(\mathrm{CN})_{4}\right]^{4-}$} & 295 & $\mathrm{H}_{2}^{2} \mathrm{O}$ & {$[50]$} \\
\hline
\end{tabular}


corresponding $\mathrm{CN}^{-}$to $\mathrm{Ru}^{\mathrm{III}}$ IS LMCT band of $\left[\mathrm{Ru}(\mathrm{CN})_{6}\right]^{3-}$ is shifted to longer wavelength $\left(\lambda_{\max }=475 \mathrm{~nm}\right)$. This shift is ascribed to the different redox potentials for the reduction of $\mathrm{Ru}^{\mathrm{III}}\left(\mathrm{E}_{1 / 2}=-0.18\right.$ for $\left[\mathrm{Ru}\left(\mathrm{NH}_{3}\right)_{6}\right]^{3+}$ and $+0.70 \mathrm{~V}$ for $\left.\left[\mathrm{Ru}(\mathrm{CN})_{6}\right]^{3-}\right)$. In addition, the larger distance between $\mathrm{CN}^{-}$and $\mathrm{Ru}^{\mathrm{III}}$ in the ion pair contributes certainly to the higher energy of the OS LMCT band.

\section{LLCT}

Intense absorption bands which are assigned to IS LLCT transitions appear in the electronic spectra of square planar $\mathrm{Ni}^{\mathrm{II}}, \mathrm{Pd}^{\mathrm{II}}$, and $\mathrm{Pt}^{\mathrm{II}}$ complexes which contain a 1,2-ethylenedithiolate as electron-donating and 1,2-diimine as accepting ligand [26]:<smiles>CC1CSC2(S1)N(C)C(=O)N(C)N2C</smiles>

It the diimine and the dithiolate are coordinated in separate complexes which form an ion pair it should be possible to identify OS LLCT absorptions. Such bands were indeed detected in the spectra of the insoluble salts $[\mathrm{Ni}(\operatorname{tim})]^{2+}\left[\mathrm{M}(\mathrm{mnt})_{2}\right]^{2-}$ with $\mathrm{M}^{\mathrm{II}}=\mathrm{Ni}^{\mathrm{II}}, \mathrm{Pd}^{\mathrm{II}}$, and $\mathrm{Pt}^{\mathrm{HI}}$ at $\lambda_{\max }=840 \mathrm{~nm}$ for $\mathrm{Ni}$, $834 \mathrm{~nm}$ for Pd, and $824 \mathrm{~nm}$ for Pt [37].

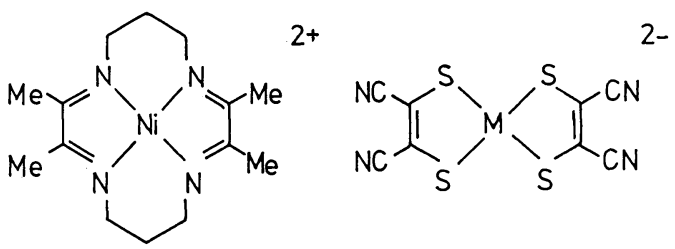

The intense and broad absorptions $\left(\varepsilon \sim 10^{4}\right)$ at about $830 \mathrm{~nm}$ were assigned to OS LLCT transitions from $\mathrm{mnt}^{2-}$ to tim. This assignment is supported by the fact that the energy of this transition is almost independent of the metal $\mathrm{M}^{\mathrm{II}}$.

\section{MMCT}

The majority of OS CT transitions of ion pairs which consist only of complex ions is of the MMCT type. The combination of the oxidizing aquo cations $\mathrm{Fe}^{\mathrm{III}}, \mathrm{Cu}^{\mathrm{II}}, \mathrm{UO}_{2}^{2+}$ and $\mathrm{VO}^{2+}$ with the reducing cyano complex anions $\left[\mathrm{Fe}^{\mathrm{II}}(\mathrm{CN})_{6}\right]^{4-}$, $\left[\mathrm{Fe}^{\mathrm{II}}(\mathrm{CN})_{5} \mathrm{~L}\right]^{3-},\left[\mathrm{Ru}^{\mathrm{II}}(\mathrm{CN})_{6}{ }^{4-},\left[\mathrm{Mo}^{\mathrm{IV}}(\mathrm{CN})_{8}\right]^{4-}\right.$ and $\left[\mathrm{W}^{\mathrm{IV}}(\mathrm{CN})_{8}\right]^{4-}$ causes also the appearance of new MMCT absorptions [38, 39]. However, it is questionable if they are OS in character. Since the aquo cations are kinetically labile and the cyano complex provide bridging ligands bi- or polynuclear complexes with an IS MMCT interaction may have been formed. For several systems this suspicion was confirmed $[38,39]$. 
Cationic $\mathrm{Co}^{\mathrm{III}}$ amine complexes are well suited as electron acceptors. When they are combined with the reducing anions $\left[\mathrm{Fe}(\mathrm{CN})_{6}\right]^{4-}[40]$ or $\left[\mathrm{Ru}(\mathrm{CN})_{6}\right]^{4-}$ $[12,41,42]$ ion pairs are formed which are characterized by OS MMCT absorption bands (Table 1). The rather short wavelength of these absorptions is certainly due to the large reorganizational energy which is associated with the reduction of low-spin $\mathrm{Co}^{\mathrm{III}}$. Since an electron is accepted into an antibonding $e_{g}$ orbital (in $\mathrm{O}_{\mathrm{h}}$ symmetry) the MMCT transition requires a large extension of the cobaltligand bond distance.

It is quite interesting to compare the MMCT transition for the ion pair (OS) $\left[\mathrm{Co}^{\mathrm{III}}\left(\mathrm{NH}_{3}\right)_{6}\right]^{3+}\left[\mathrm{Ru}^{\mathrm{II}}(\mathrm{CN})_{6}\right]^{4-}\left(\lambda_{\max }=344 \mathrm{~nm}\right)[12,41,42]$ and the related binuclear complex (IS) $\left[\left(\mathrm{NH}_{3}\right)_{5} \mathrm{Co}^{\mathrm{III}} \mathrm{NCRu}^{\mathrm{II}}(\mathrm{CN})_{5}\right]^{-}\left(\lambda_{\max }=375 \mathrm{~nm}\right)[12,43]$. The blue shift for the ion pair is probably caused - at least partially - by the larger distance between the metal centers as redox sites.

A distance effect was also expected for the ion pairs $\left[\mathrm{CoL}_{6}\right]^{3+}\left[\mathrm{Ru}(\mathrm{CN})_{6}\right]^{4-}$ with $\left[\mathrm{Co}(\mathrm{N}-\mathrm{N})_{3}\right]^{3+}$ with $\mathrm{N}-\mathrm{N}=$ ethylenediamine, 1,2-diaminopropane, and 1,2cyclohexanediamine since the ligands become larger in this series [12, 42]. However, contrary to the expectation the OS MMCT bands were shifted to longer wavelength (Table 1). The distance between donor and acceptor grew apparently. It is assumed that the increasing size of the complex cations is indeed associated with a decreasing size of the solvated cobalt complexes in the ion pair. This phenomenon is well known for alkali cations. It is certainly also favored by the hydrophobicity of the Co complexes which becomes larger when the number of alkyl substituents at the diamine ligand increases.

The largest number of ion pairs which display OS MMCT bands was observed with octahedral ammine complexes of $\mathrm{Ru}^{\mathrm{III}}$ as acceptor and $\left[\mathrm{Fe}^{\mathrm{II}}(\mathrm{CN})_{6}\right]^{4-}[44-46]$ $\left[\mathrm{Fe}^{\mathrm{II}}(\mathrm{CN})_{5} \mathrm{~L}\right]^{3-}[45],\left[\mathrm{Ru}(\mathrm{CN})_{6}\right]^{4-}[4447]$, and $\left[\mathrm{Os}(\mathrm{CN})_{6}\right]^{4-}[46]$ as donor (Table 1). Since $\mathrm{Ru}^{\mathrm{III}}$ is a $\mathrm{d}^{5}$ metal the lowest-energy MMCT transition terminates in the hole of the $t_{2 g}$ orbitals. Due to the non-bonding character of these orbitals the reorganizational energy is obviously much smaller than for low-spin $\mathrm{Co}^{\mathrm{III}}$. In fact, the reorganizational energy of all these $\mathrm{Ru}^{\mathrm{III}} / \mathrm{Fe}^{\mathrm{II}}, \mathrm{Ru}^{\mathrm{II}}$, and $\mathrm{Os}^{\mathrm{II}}$ ion pairs seems to be rather similar. This assumption is supported by the observation that the energy of the MMCT transition is proportional to the redox asymmetry $\triangle \mathrm{E}$ $[45,46]$. For a homonuclear ion pair $\Delta \mathrm{E}$ is generally rather small but can become rather large in suitable cases. It is as large as $0.90 \mathrm{~V}$ for $\left[\mathrm{Ru}^{\mathrm{III}}\left(\mathrm{NH}_{3}\right)_{5} \mathrm{Cl}\right]^{2+}\left[\mathrm{Ru}^{\mathrm{II}}-\right.$ $\left.(\mathrm{CN})_{6}\right]^{4-}$ since the $\mathrm{NH}_{3}$ and $\mathrm{Cl}^{-}$ligands stabilize the oxidation state III while $\mathrm{CN}^{-}$as a $\pi$-accepting ligand favors $\mathrm{Ru}^{\mathrm{II}}$ [47]. For many of these ion pairs it has been confirmed that electronic coupling between donor and acceptor is indeed rather small.

The ion pairs $\left[\mathrm{Os}^{\mathrm{III}}\left(\mathrm{NH}_{3}\right)_{5} \mathrm{Cl}\right]^{2+}\left[\mathrm{M}^{\mathrm{II}}(\mathrm{CN})_{6}\right]^{4-}(\mathrm{M}=\mathrm{Fe}, \mathrm{Ru}, \mathrm{Os})$ display also long-wavelength OS MMCT bands $[12,42]$ (Table 1). Since $\left[\mathrm{Os}\left(\mathrm{NH}_{3}\right)_{5} \mathrm{Cl}\right]^{2+}$ is much less oxidizing $(-1.10 \mathrm{~V})$ than $\left[\mathrm{Ru}\left(\mathrm{NH}_{3}\right)_{5} \mathrm{Cl}\right]^{2+}(-0.04 \mathrm{~V})$ the MMCT absorptions of the ion pairs which contain $\mathrm{Os}^{\mathrm{III}}$ as acceptor appear at shorter wavelength than those of $\mathrm{Ru}^{\text {IIII }}$.

Upon addition of aqueous solutions of $\mathrm{Eu}^{3+}$ to $\left[\mathrm{M}(\mathrm{CN})_{6}\right]^{4-}$ with $\mathrm{M}=\mathrm{Fe}$, $\mathrm{Ru}$, and $\mathrm{Os}$ insoluble salts precipitate. If $\mathrm{Eu}^{3+}$ is incorporated into a cryptand (C 2.2.1 = 4,7,13,16,21-pentaoxo-1,10-diazabicyclo-[8.8.5]tricosane) the cationic 
cryptate $\left[\mathrm{Eu}^{\mathrm{III}} \mathrm{C} 2.2 .1\right]^{3+}$ forms soluble ion pairs with $\left[\mathrm{M}(\mathrm{CN})_{6}\right]^{4-}$. These pairs are characterized by $\mathrm{M}^{\mathrm{II}}$ to $\mathrm{Eu}^{\mathrm{III}}$ OS MMCT absorptions $[14,48,49]$ (Table 1). The MMCT state $\left(\mathrm{Eu}^{\mathrm{II}} / \mathrm{M}^{\mathrm{III}}\right)$ can be also generated by excited state electron transfer. That portion of [EuC2.2.1 ${ }^{3+}$ which is not ion-paired is luminescent but the emission is quenched by electron transfer in diffusional encounters.

The ion pairs $\left[\mathrm{Pt}^{\mathrm{IV}}\left(\mathrm{NH}_{3}\right)_{5} \mathrm{Cl}\right]^{3+}\left[\mathrm{M}^{\mathrm{II}}(\mathrm{CN})_{6}\right]^{4-}(\mathrm{M}=\mathrm{Fe}, \mathrm{Ru}, \mathrm{Os})$ show $\mathrm{M}^{\mathrm{II}}$ to $\mathrm{Pt}^{\mathrm{IV}}$ OS MMCT bands at rather short wavelength [50] (Table 1) although the $\mathrm{Pt}^{\mathrm{IV}}$ complex is an oxidant of moderate strength. However, the potentials of $\mathrm{Pt}^{\mathrm{IV}}$ complexes are generally known only for two-electron reductions to $\mathrm{Pt}^{\mathrm{II}}$ while the optical MMCT transition as a one-electron process could require much larger energies since $\mathrm{Pt}^{\mathrm{III}}$ may be a high-energy intermediate of the reduction from $\mathrm{Pt}^{\mathrm{IV}}$ to $\mathrm{Pt}^{\mathrm{II}}$. Since the MMCT transition terminates in an antibonding $e_{g}$ orbital of $\mathrm{Pt}^{\mathrm{IV}}$ a large reorganizational energy contributes certainly also to the short wavelength of the MMCT band.

The $\mathrm{Pt}^{\mathrm{Il}}$ to $\mathrm{Pt}^{\mathrm{IV}} \mathrm{OS}$ MMCT absorption of the ion pair $\left[\mathrm{Pt}\left(\mathrm{NH}_{3}\right)_{5} \mathrm{Cl}\right]^{3+}\left[\mathrm{Pt}(\mathrm{CN})_{4}\right]^{2-}$ undergoes a further blue shift [50] (Table 1) because the MMCT transition generates now two high-energy $\mathrm{Pt}^{\mathrm{III}}$ centers. In addition, the oxidation of $\mathrm{Pt}^{\mathrm{II}}$ is associated with a huge reorganizational energy since new ligands must be attached to the square planar complex.

\section{MMCT of Organometallic Ion Pairs}

Organometallic ion pairs which exhibit OS MMCT bands in their electronic spectra have been described only recently. Many salts which contain an oxidizing metal carbonyl or metallocenium cation and a reducing metal carbonyl anion were prepared and characterized a long time ago. However, studies of the optical spectra were not included in the early work. The occurance of OS MMCT absorptions of organometallic ion pairs is not only interesting in its own right but is also of general importance with regard to electron transfer processes in organometallic chemistry [51]. The first example of an organometallic ion pair with an OS MMCT band was reported by Schramm and Zink in 1979. They detected a $\mathrm{Co}^{-\mathrm{I}}$ to $\mathrm{Tl}^{\mathrm{l}} \mathrm{CT}$ absorption of the ion pair $\mathrm{Tl}^{+}\left[\mathrm{Co}(\mathrm{CO})_{4}\right]^{-}$(Table 2) [52].

A very general type of organometallic ion pairs is composed of an oxidizing metal carbonyl cation and a reducing metal carbonyl anion. Some of these

Table 2. Optical OS CT (metal to metal) transitions of organometallic ion pairs

\begin{tabular}{lllll}
\hline Acceptor & Donor & $\begin{array}{l}\text { Abs. } \\
\lambda_{\text {max }} / \mathrm{nm}\end{array}$ & Solvent & Ref. \\
\hline $\mathrm{Tl}^{+}$ & {$\left[\mathrm{Co}(\mathrm{CO})_{4}\right]^{-}$} & 400 & $\mathrm{CH}_{3} \mathrm{CN}$ & {$[52]$} \\
{$\left[\mathrm{Co}(\mathrm{CO})_{3}\left(\mathrm{PPh}_{3}\right)_{2}\right]^{+}$} & {$\left[\mathrm{Co}(\mathrm{CO})_{4}\right]^{-}$} & 386 & acetone & {$[54]$} \\
{$\left[\mathrm{Co}\left(\mathrm{C}_{5} \mathrm{H}_{5}\right)_{2}\right]^{+}$} & {$\left[\mathrm{Co}(\mathrm{CO})_{4}\right]^{-}$} & 520 & $\mathrm{CH}_{2} \mathrm{Cl}_{2}$ & {$[59]$} \\
{$\left[\mathrm{Co}\left(\mathrm{C}_{5} \mathrm{H}_{5}\right)_{2}\right]^{+}$} & {$\left[\mathrm{Mn}(\mathrm{CO})_{5}\right]^{-}$} & 740 & solid & {$[60]$} \\
{$\left[\mathrm{Cr}\left(\mathrm{C}_{6} \mathrm{H}_{6}\right)_{3}\right]^{+}$} & {$\left[\mathrm{Mn}(\mathrm{CO})_{5}\right]^{-}$} & 665 & solid & {$[60]$} \\
\hline
\end{tabular}


salts can be prepared by thermal or photochemical disproportionation of dimeric metal carbonyls in the presence of free ligand, e.g. [53]:

$$
\left[\mathrm{Co}_{2}^{0}(\mathrm{CO})_{8}\right]+2 \mathrm{PPh}_{3} \rightarrow\left[\mathrm{Co}^{\mathrm{I}}(\mathrm{CO})_{3}\left(\mathrm{PPh}_{3}\right)_{2}\right]^{+}\left[\mathrm{Co}^{-1}(\mathrm{CO})_{4}\right]^{-}+\mathrm{CO}
$$

This $\mathrm{Co}^{\mathrm{I}} / \mathrm{Co}^{-\mathrm{I}}$ ion pair is characterized by an OS MMCT absorption in the visible region [54] (Table 2). In addition, a large number of salts which contain the electron acceptors $\left[\mathrm{M}(\mathrm{CO})_{6}\right]^{+},\left[\mathrm{M}(\mathrm{CO})_{5} \mathrm{~L}\right]^{+}$and $\left[\mathrm{M}(\mathrm{CO})_{4} \mathrm{~L}_{2}\right]^{+}$with $\mathrm{M}^{\mathrm{I}}=\mathrm{Mn}$ [55] and $\mathrm{Re}[56]$ and $\mathrm{L}=\mathrm{PPh}_{3}$ or $\mathrm{L}_{2}=0$-phen and the electron donors $\left[\mathrm{Co}(\mathrm{CO})_{4}\right]^{-}$, $\left[\mathrm{V}(\mathrm{CO})_{6}\right]^{-},\left[\mathrm{Fe}(\mathrm{CO})_{3} \mathrm{NO}\right]^{-}$, and $\left[\mathrm{Mn}(\mathrm{CO})_{5}\right]^{-}$was synthesized. While most of these ions are colorless the salts are generally colored. Although electronic spectra were not recorded the colors originate probably from OS MMCT transitions.

The organometallic ion pairs which are composed of the oxidizing cations $\left[\mathrm{Co}\left(\mathrm{C}_{5} \mathrm{H}_{5}\right)_{2}\right]^{+}$or $\left[\mathrm{Cr}\left(\mathrm{C}_{6} \mathrm{H}_{6}\right)_{2}\right]^{+}$and the reducing anions $\left[\mathrm{Co}(\mathrm{CO})_{4}\right]^{-},\left[\mathrm{FeH}(\mathrm{CO})_{4}\right]^{-}$, $\left.\left[\mathrm{Cr}\left(\mathrm{C}_{5} \mathrm{H}_{5}\right)(\mathrm{CO})_{3}\right]^{-}, \mathrm{Mn}(\mathrm{CO})_{5}\right]^{-}$, and $\left[\mathrm{V}(\mathrm{CO})_{6}\right]^{-}$are also remarkably colored $[57,58]$. In some cases it was confirmed that the colors are due to OS MMCT bands $[59,60]$ (Table 2 ).

\subsubsection{Ion Pairs Consisting of a Complex and a Non-metallic Counter Ion}

Complex to Acceptor CT

There is a large number of oxidizing organic cations which can serve as electron acceptors for reducing metal complex anions. Spectral data on these OS CT transitions are given in Table 3. With regard to the metal complex a distinction between the metal and the ligand as the donor site can be made. Frequently cyano complexes were used as donors [31,61-66]. A detailed theoretical treatment of the ion pair 1,1'-dimethyl-4,4'-bipyridinium ${ }^{2+}\left[\mathrm{Fe}(\mathrm{CN})_{6}\right]^{4-}\left(1,1^{\prime}\right.$ dimethyl-4,4'-bipyridinium ${ }^{2+}$ is also called paraquat $^{2+}$ or methylviologen ${ }^{2+}$ ) was published by Curtis, Sullivan, and Meyer [63]. Besides classical cyano complexes also metal carbonyl anions such as $\left[\mathrm{Co}(\mathrm{CO})_{4}\right]^{-}[15,67]$ and $\left[\mathrm{M}(\mathrm{CO})_{6}\right]^{-}$ with $\mathrm{M}=\mathrm{V}, \mathrm{Nb}$, and $\mathrm{Ta}$ [68-70] are suitable donors. The central metal is the donor site of the cyano and carbonyl complex anions.

Another rather interesting type of reducing complex anion contains the chelating 1,2-ethylenedithiolate ligand (see above). Many ion pairs which are composed of such donating complex anions and organic accepting cations were shown to display OS CT bands [71-74] (Table 3). It seems that for most of these ion pairs the donor site is located at the dithiolate ligands. In the case of the complex $\mathrm{Zn}\left[\mathrm{S}_{2} \mathrm{C}_{2}(\mathrm{CN})_{2}\right]_{2}^{2-}[72,73]$ this assumption is certainly correct since $\mathrm{Zn}^{2+}$ cannot participate in any low-energy CT transitions.

\section{Donor to Complex CT}

Many ion pairs which are composed of oxidizing complex cations and non-metallic reducing anions display OS CT bands in their electronic spectra [15]. The acceptor site may be again the metal or the ligand. 
‡ Table 3. Optical OS CT (complex to acceptor) transitions of ion pairs consisting of a non-metallic cation and a complex anion

\begin{tabular}{|c|c|c|c|c|}
\hline Acceptor & Donor & $\begin{array}{l}\text { Abs. } \\
\lambda_{\max } / \mathrm{nm}\end{array}$ & Solvent & Ref. \\
\hline paraquat $^{2+}$ & {$\left[\mathrm{Fe}(\mathrm{CN})_{6}\right]^{4-}$} & 530 & $\mathrm{H}_{2} \mathrm{O}$ & {$[63]$} \\
\hline $\mathrm{Ph}_{2} \mathrm{I}^{+}$ & {$\left[\mathrm{Fe}(\mathrm{CN})_{6}\right]^{4-}$} & 406 & $\mathrm{CH}_{3} \mathrm{OH}$ & {$[65]$} \\
\hline $\mathrm{Ph}_{2}^{2} \mathrm{I}^{+}$ & {$\left[\mathrm{Fe}(\mathrm{CN})_{5} \text { dimethylsulfoxide }\right]^{3-}$} & 333 & $\mathrm{CH}_{3} \mathrm{OH}$ & {$[65]$} \\
\hline paraquat $^{2+}$ & {$\left[\mathrm{Fe}(\mathrm{CN})_{5}(\text { imidazole })\right]^{3-}$} & 555 & $\mathrm{H}_{2} \mathrm{O}$ & [62] \\
\hline paraquat $^{2+}$ & {$\left[\mathrm{Fe}(\mathrm{CN})_{5} \mathrm{PPh}_{3}\right]^{3-}$} & 507 & $\mathrm{H}_{2}^{2} \mathrm{O}$ & {$[62]$} \\
\hline paraquat $^{2+}$ & {$\left[\mathrm{Fe}(\mathrm{CN})_{5}(\text { pyridine })\right]^{3-}$} & 532 & $\mathrm{H}_{2}^{2} \mathrm{O}$ & {$[62]$} \\
\hline paraquat $^{2+}$ & {$\left[\mathrm{Fe}(\mathrm{CN})_{5}(\text { dimethylsulfoxide })\right]^{3-}$} & 450 & $\mathrm{H}_{2} \mathrm{O}$ & {$[62]$} \\
\hline paraquat $^{2+}$ & {$\left[\mathrm{Fe}(\mathrm{CN})_{5} \mathrm{CO}\right]^{3-}$} & 400 & $\mathrm{H}_{2} \mathrm{O}$ & {$[62]$} \\
\hline paraquat $^{2+}$ & {$\left[\mathrm{Ru}(\mathrm{CN})_{6}\right]^{4-}$} & 416 & $\mathrm{H}_{2}^{2} \mathrm{O}$ & [31] \\
\hline $\mathrm{Ph}_{2} \mathrm{I}^{+}$ & {$\left[\mathrm{Ru}(\mathrm{CN})_{6}\right]^{4-}$} & 340 & $\mathrm{CH}_{3} \mathrm{OH}$ & [65] \\
\hline 1-ethyl-1-carboxymethylpyridinium ${ }^{+}$ & {$\left[\mathrm{Ru}(\mathrm{CN})_{6}\right]^{4-}$} & 442 & $\mathrm{CH}_{3} \mathrm{OH}$ & [31] \\
\hline 4-methoxyphenyldiazonium ${ }^{+}$ & {$\left[\mathrm{Ru}(\mathrm{CN})_{6}\right]^{4-}$} & 375 & $\mathrm{H}_{2} \mathrm{O}$ & [66] \\
\hline 1-ethyl-2-carboxymethylpyridium ${ }^{+}$ & {$\left[\mathrm{Mn}(\mathrm{CN})_{5} \mathrm{NO}\right]^{3-}$} & 429 & $\mathrm{H}_{2}^{2} \mathrm{O}$ & [31] \\
\hline paraquat $^{2+}$ & {$\left[\mathrm{Mn}(\mathrm{CN})_{5} \mathrm{NO}\right]^{3-}$} & 513 & $\mathrm{H}_{2} \mathrm{O}$ & {$[31]$} \\
\hline $\mathrm{Ph}_{2} \mathrm{I}^{+}$ & {$\left[\mathrm{Mn}(\mathrm{CN})_{5} \mathrm{NO}\right]^{3-}$} & 389 & $\mathrm{CH}_{3} \mathrm{OH}$ & [65] \\
\hline $\mathrm{Ph}_{2} \mathrm{I}^{+}$ & {$\left[\mathrm{Mo}(\mathrm{CN})_{8}\right]^{4-}$} & 370 & $\mathrm{CH}_{3} \mathrm{OH}$ & [65] \\
\hline 1-ethyl-1-carboxymethylpyriduum ${ }^{+}$ & {$\left[\mathrm{Mo}(\mathrm{CN})_{8}\right]^{4-}$} & 444 & $\mathrm{H}_{2} \mathrm{O}$ & [31] \\
\hline 1-methylchinoxalinium ${ }^{+}$ & {$\left[\mathrm{Mo}(\mathrm{CN})_{8}\right]^{4-}$} & 529 & $\mathrm{H}_{2}^{2} \mathrm{O}$ & [31] \\
\hline paraquat $^{2+}$ & {$\left[\mathrm{Mo}(\mathrm{CN})_{8}\right]^{4-}$} & 505 & $\mathrm{H}_{2} \mathrm{O}$ & [31] \\
\hline paraquat $^{2+}$ & {$\left[\mathrm{W}(\mathrm{CN})_{8}\right]^{4-}$} & 575 & $\mathrm{H}_{2} \mathrm{O}$ & [31] \\
\hline 1-ethyl-1-carboxymethylpyridium ${ }^{+}$ & {$\left[\mathrm{W}(\mathrm{CN})_{8}\right]^{4-}$} & 490 & $\mathrm{H}_{2} \mathrm{O}$ & {$[31]$} \\
\hline 1-methylchinoxylinium ${ }^{+}$ & {$\left[\mathrm{W}(\mathrm{CN})_{8}\right]^{4-}$} & 602 & $\mathrm{H}_{2} \mathrm{O}$ & {$[31]$} \\
\hline $\mathrm{Ph}_{2} \mathrm{I}^{+}$ & {$\left[\mathrm{W}(\mathrm{CN})_{8}\right]^{4-}$} & 400 & $\mathrm{CH}_{3} \mathrm{OH}$ & [65] \\
\hline pyridinium $^{+}$ & {$\left[\mathrm{Co}(\mathrm{CO})_{4}\right]^{-}$} & 415 & butane-2-one & {$[15,67]$} \\
\hline 1-ethyl-4-carbomethoxypyridinium ${ }^{+}$ & $\begin{array}{l}{\left[\mathrm{Ni}(\mathrm{mnt})_{2}\right]^{2-}} \\
(\mathrm{mnt}=\text { maleonitriledithiolate })\end{array}$ & 675 & solid & [71] \\
\hline 4-cyano-1-methylpyridinium ${ }^{+}$ & $\begin{array}{l}{\left[\mathrm{Ni}(\mathrm{mnt})_{2}\right]^{2-}} \\
(\mathrm{mnt}=\text { maleonitriledithiolate })\end{array}$ & 654 & solid & [71] \\
\hline 4-cyano-1-ethylpyridinium ${ }^{+}$ & $\begin{array}{l}{\left[\mathrm{Ni}(\mathrm{mnt})_{2}\right]^{2-}} \\
(\mathrm{mnt}=\text { maleonitriledithiolate })\end{array}$ & 680 & solid & [71] \\
\hline
\end{tabular}


4-cyano-1-butylpyridinium ${ }^{+}$

1-methylpyridinium ${ }^{+}$

1-ethyl-4-carbomethoxypyridinium ${ }^{+}$

4-cyano-1-methylpyridinium ${ }^{+}$

4-cyano-1-butylpyridinium ${ }^{+}$

1-methylpyridinium ${ }^{+}$

1-ethyl-4-carbomethoxypyridinium ${ }^{+}$ 4-cyano-1-butylpyridinium ${ }^{+}$

1-methylpyridinium ${ }^{+}$

1-ethyl-4-carbomethoxypyridinium ${ }^{+}$

1-ethyl-4-carbomethoxypyridinium ${ }^{+}$

4-cyano-1-methylpyridinium ${ }^{+}$

4-cyano-1-ethylpyridinium ${ }^{+}$

paraquat $^{2+}$

paraquat $^{2+}$

paraquat $^{2+}$

paraquat $^{2+}$

paraquat $^{2+}$

paraquat $^{2+}$

paraquat $^{2+}$

paraquat $^{2+}$

paraquat $^{2+}$

1,1'-dioctyl-4,4'-bipyridinium ${ }^{2+}$

1,1'-dioctyl-4,4'-bipyridinium ${ }^{2+}$

$1,1^{\prime}$-dioctyl-4,4'-bipyridinium ${ }^{2+}$

paraquat $^{2+}$
$\left[\mathrm{Ni}(\mathrm{mnt})_{2}\right]^{2-}$

$(\mathrm{mnt}=$ maleonitriledithiolate $)$

$\left[\mathrm{Ni}(\mathrm{mnt})_{2}\right]^{2-}$

$(\mathrm{mnt}=$ maleonitriledithiolate $)$

[Ni(1,2-bis(trifluoromethylethylene-

1,2-dithiolate $\left.)_{2}\right]^{2-}$

[Ni(1,2-bis(trifluoromethylethylene-

1,2-dithiolate) $\left.]_{2}\right]^{2-}$

[Ni(1,2-bis(trifluoromethylethylene-

1,2-dithiolate) $\left.{ }_{2}\right]^{2-}$

[Ni(1,2-bis(trifluoromethylethylene-

1,2-dithiolate) $\left.{ }_{2}\right]^{2-}$

$\left[\mathrm{Co}(\mathrm{mnt})_{2}\right]^{2-}$

$\left[\mathrm{Co}(\mathrm{mnt})_{2}\right]^{2-}$

$\left[\mathrm{Co}(\mathrm{mnt})_{2}\right]^{2-}$

$\left[\mathrm{Cu}(\mathrm{mnt})_{2}\right]^{2}$

$\left[\mathrm{Zn}(\mathrm{mnt})_{2}\right]^{2-}$

$\left[\mathrm{Zn}(\mathrm{mnt})_{2}\right]^{2-}$

$\left[\mathrm{Zn}(\mathrm{mnt})_{2}\right]^{2-}$

$\left[\mathrm{Zn}(\mathrm{mnt})_{2}\right]^{2-}$

$\left[\mathrm{Cd}(\mathrm{mnt})_{2}\right]^{2-}$

$\left[\mathrm{Hg}(\mathrm{mnt})_{2}\right]^{2-}$

$\left[\mathrm{Zn}(2,3 \text {-chinoxalinedithiolate })_{2}\right]^{2-}$

$\left[\mathrm{Cd}(2,3 \text {-chinoxalinedithiolate })_{2}\right]^{2-}$

$\left[\mathrm{Hg}(2,3 \text {-chinoxalinedithiolate })_{2}\right]^{2-}$

$\left[\mathrm{Zn}(\mathrm{ddt})_{2}\right]^{2-}$

$(\mathrm{ddt}=2$-thiooxo-1,3-dithiol-4,5-dithiolate $)$

$\left.[\mathrm{Cd}(\mathrm{ddt})]_{2}\right]^{-}$

$\left[\mathrm{Hg}(\mathrm{ddt})_{2}\right]^{2-}$

$\left[\mathrm{Zn}(\mathrm{ddt})_{2}\right]^{2-}$

$\left[\mathrm{Cd}(\mathrm{ddt})_{2}\right]^{2-}$

$\left[\mathrm{Hg}(\mathrm{ddt})_{2}\right]^{2-}$

$\left[\operatorname{Ir}(\mathrm{CO})_{2}(\mathrm{mnt})\right]^{-}$

$\left[\operatorname{Ir}\left(\mathrm{P}\left(\mathrm{OPh}_{3}\right)_{3}\right)_{2}(\mathrm{mnt})\right]^{-}$
658

solid

$\sim 634$

solid

714

solid

806

solid

781

solid

[71

552

solid

solid

$\sim 669$

solid

solid

solid

solid

solid

solid

dmso

dmso

dmso

dmso

dmso

dmso

dmso

[71]

465

500

460

470
448

452

456

655

dmso

dmso

dmso

dmso

dmso

$\mathrm{CH} \mathrm{CN}$

$\mathrm{CH}_{3} \mathrm{CN}$ 
Table 4. Optical OS CT (donor to complex) transitions of ion pairs consisting of a complex cation and a non-metallic anion

\begin{tabular}{|c|c|c|c|c|}
\hline Acceptor & Donor & $\begin{array}{l}\text { Abs. } \\
\lambda_{\text {max }} / \mathrm{nm}\end{array}$ & Solvent & Ref. \\
\hline$\left[\mathrm{Co}\left(\mathrm{NH}_{3}\right)_{6}\right]^{3+}$ & $\mathrm{I}^{-}$ & 272 & $\mathrm{H}_{2} \mathrm{O}$ & {$[75 ; 76]$} \\
\hline$\left[\mathrm{Co}(\mathrm{en})_{3}\right]^{3+}$ & $\mathrm{I}^{-}$ & 278 & $\mathrm{H}_{2}^{2} \mathrm{O}$ & [77] \\
\hline$\left[\mathrm{Co}(\mathrm{en})_{3}\right]^{3+}$ & $\mathrm{SCN}^{-}$ & 285 & $\mathrm{H}_{2}^{2} \mathrm{O}$ & {$[31]$} \\
\hline$\left[\mathrm{Co}(1,2 \text {-propanediamine })_{3}\right]^{3+}$ & $\mathrm{I}^{-}$ & 286 & $\mathrm{H}_{2} \mathrm{O}$ & [77] \\
\hline$\left[\mathrm{Co}(\text { diethylenetriamine })_{2}\right]^{3+}$ & $\mathrm{I}^{-}$ & 294 & $\mathrm{H}_{2}^{2} \mathrm{O}$ & [77] \\
\hline$[\mathrm{Co}(\mathrm{sep})]^{3+}$ & $\mathrm{I}^{-}$ & 289 & $\mathrm{H}_{2} \mathrm{O}$ & {$[78,79]$} \\
\hline$[\mathrm{Co}(\mathrm{sep})]^{3+}$ & $\mathrm{Br}^{-}$ & 272 & $\mathrm{H}_{2}^{2} \mathrm{O}$ & [78] \\
\hline$[\mathrm{Co}(\mathrm{sep})]^{3+}$ & $\mathrm{Cl}^{-}$ & 263 & $\mathrm{H}_{2}^{2} \mathrm{O}$ & [78] \\
\hline$[\mathrm{Co}(\mathrm{sep})]^{3+}$ & $\mathrm{NCS}^{-}$ & 284 & $\mathrm{H}_{2} \mathrm{O}$ & [78] \\
\hline$[\mathrm{Co}(\mathrm{sep})]^{3+}$ & $\mathrm{C}_{2} \mathrm{O}_{4}^{2-}$ & 275 & $\mathrm{H}_{2} \mathrm{O}$ & {$[78,80]$} \\
\hline$[\mathrm{Co}(\operatorname{sep})]^{3+}$ & $\mathrm{BPh}_{4}^{-}$ & 530 & $\mathrm{CH}_{3} \mathrm{CN}$ & {$[81]$} \\
\hline$\left[\mathrm{Ru}\left(\mathrm{NH}_{3}\right)_{5} \text { pyridine }\right]^{3+}$ & $\mathrm{Cl}^{-4}$ & 312 & $\mathrm{H}_{2} \mathrm{O}$ & [83] \\
\hline$\left[\mathrm{Ru}\left(\mathrm{NH}_{3}\right)_{5} \text { pyridine }\right]^{3+}$ & $\mathrm{Br}^{-}$ & 338 & $\mathrm{H}_{2}^{2} \mathrm{O}$ & [83] \\
\hline$\left[\mathrm{Ru}\left(\mathrm{NH}_{3}\right)_{5} \text { pyridine }\right]^{3+}$ & $\mathrm{SCN}^{-}$ & 400 & $\mathrm{H}_{2}^{2} \mathrm{O}$ & [83] \\
\hline$\left[\mathrm{Ru}\left(\mathrm{NH}_{3}\right)_{5} \text { pyridine }\right]^{3+}$ & $\mathrm{I}^{-}$ & 410 & $\mathrm{H}_{2}^{2} \mathrm{O}$ & [83] \\
\hline$\left[\mathrm{Ru}\left(\mathrm{NH}_{3}\right)_{5} \text { pyridine }\right]^{3+}$ & $\mathrm{C}_{2} \mathrm{O}_{4}^{2-}$ & 409 & $\mathrm{H}_{2} \mathrm{O}$ & {$[83$} \\
\hline$\left[\mathrm{Ru}\left(\mathrm{NH}_{3}\right)_{6}\right]^{3+}$ & $\mathrm{Cl}^{-4}$ & 294 & $\mathrm{H}_{2} \mathrm{O}$ & {$[82,83]$} \\
\hline$\left[\mathrm{Ru}\left(\mathrm{NH}_{3}\right)_{6}\right]^{3+}$ & $\mathrm{Br}^{-}$ & 306 & $\mathrm{H}_{2}^{2} \mathrm{O}$ & {$[82,83]$} \\
\hline$\left[\mathrm{Ru}\left(\mathrm{NH}_{3}\right)_{6}\right]^{3+}$ & $\mathrm{I}^{-}$ & 402 & $\mathrm{H}_{2}^{2} \mathrm{O}$ & {$[82,83]$} \\
\hline$\left[\mathrm{Ru}\left(\mathrm{NH}_{3}\right)_{6}\right]^{3+}$ & $\mathrm{CN}^{-}$ & 406 & $\mathrm{H}_{2}^{2} \mathrm{O}$ & [36] \\
\hline$\left[\mathrm{Ru}\left(\mathrm{NH}_{3}\right)_{5}\left(\mathrm{CH}_{3} \mathrm{CN}\right)\right]^{3+}$ & $\mathrm{Cl}^{-}$ & 318 & $\mathrm{H}_{2}^{2} \mathrm{O}$ & [83] \\
\hline$\left[\mathrm{Ru}\left(\mathrm{NH}_{3}\right)_{5}\left(\mathrm{CH}_{3} \mathrm{CN}\right)\right]^{3+}$ & $\mathrm{Br}^{-}$ & 334 & $\mathrm{H}_{2} \mathrm{O}$ & [83] \\
\hline \multirow[t]{2}{*}[\operatorname{Ru}(\mathrm{en})_{3}]{$^{3+}$} & $\mathrm{I}^{-}$ & 450 & $\mathrm{H}_{2} \mathrm{O}$ & [84] \\
\hline & & 483 & solid & [84] \\
\hline$\left[\operatorname{Ru}(\mathrm{en})_{3}\right]^{3+}$ & $\mathrm{Br}^{-}$ & 370 & $\mathrm{H}_{2} \mathrm{O}$ & [84] \\
\hline
\end{tabular}

The majority of observations on OS donor to metal CT absorptions were made with ion pairs which contain cationic amine complexes of $\mathrm{Co}^{\mathrm{III}}$ [75-81] and $\mathrm{Ru}^{\text {III }}$ [82-84] as acceptors (Table 4). In addition, fulvalendiyl Co ${ }^{\text {III }}$ complexes were used as oxidizing cations [85]. A variety of donor anions such as the halides are suitable. The wavelength of the OS CT bands decreases with decreasing reducing strength of the halide $\left(\mathrm{I}^{-}>\mathrm{Br}^{-}>\mathrm{Cl}^{-}\right)$. In this context it is certainly of interest that $\left[\mathrm{Co}\left(\mathrm{NH}_{3}\right)_{6}\right]^{3+} \mathrm{I}^{-}$was the first ion pair of a metal complex which was reported to show an OS CT absorption [75, 76]. The colors of the salts $\left[\operatorname{Ir}\left(\mathrm{NH}_{3}\right)_{6}\right]^{3+}$ halide $^{-}$may be also caused by OS CT bands although the spectra of these ion pairs were not recorded [86].

Instead of an oxidizing metal the coordinated bipy ligand can also act as electron acceptor. For example, OS donor to ligand CT absorptions determine the colors of the salts $\left[\mathrm{Rh}^{\mathrm{III}}(\text { bipy })_{3}\right]^{3+} \mathrm{X}_{3}^{-}$with $\mathrm{X}^{-}=\mathrm{Cl}^{-}, \mathrm{Br}^{-}, \mathrm{SCN}^{-}$, and $\mathrm{CN}^{-}$. Harris and McKenzie made this observation already in 1963 and suggested a CT transition from $\mathrm{X}^{-}$to to complex as origin of the colors [87]. Since $\mathrm{Rh}^{\mathrm{III}}$ is rather redox inert there is little doubt that the OS CT transition terminates indeed in the $\pi^{*}$ orbitals of the diimine ligand. 


\subsection{Neutral Acceptors and/or Donors}

\section{Complex to Acceptor CT}

The necessary close contact for an OS CT interaction is not only provided by the electrostatic attraction within an ion pair. If the solvent is the donor or acceptor an inimate interaction with a dissolved complex as the acceptor or donor is certainly also guaranteed. While optical OS solvent to complex CT transitions have not yet been identified many reducing complexes are well known to display complex to solvent CT (,CTTS = CT to solvent") bands if they are dissolved in oxidizing solvents such as halogenated alkanes or even water $[8,19,33]$. The donor complex can be charged or neutral. Examples are the cations $\left[\mathrm{Ru}^{\mathrm{II}}\left(\mathrm{NH}_{3}\right)_{6}\right]^{2+}$ [88] and $\left[\mathrm{Co}_{2}(\text { fulvalendiyl })_{2}\right]^{+}[85]$, the anions $[89,90]$ $\left[\mathrm{M}^{\mathrm{II}}(\mathrm{CN})_{6}\right]^{4-}(\mathrm{M}=\mathrm{Fe}, \mathrm{Ru})$ and $\left[\mathrm{M}^{\mathrm{IV}}(\mathrm{CN})_{8}\right]^{4-}(\mathrm{M}=\mathrm{Mo}, \mathrm{W})$ and the neutral complexes ferrocene $[91,92]$ and $\left[\left(\mathrm{C}_{5} \mathrm{H}_{5}\right) \mathrm{Fe}(\mathrm{CO})\right]_{4}$ [93]. The complex to solvent CT bands involving these complexes are usually not well resolved since they appear in the short-wavelength region where they interfere with absorptions of a different origin. Since these complex to solvent CT transitions have been discussed in several reviews $[8,19,33]$ any further description is not necessary here.

OS complex to acceptor CT bands were also observed upon association of $\left[\mathrm{M}^{0}\right.$ (arene) $\left.(\mathrm{CO})_{3}\right](\mathrm{M}=\mathrm{Cr}, \mathrm{Mo}, \mathrm{W})$ as neutral electron donors and trinitrobenzene (TNB) or tetracyanoethylene (TCNE) as neutral electron acceptors [94-98]. Generally, the CT absorptions appear only for the solid addition compounds while a dissociation into the separate components takes place in solution. The CT interaction occurs by coplanar face to face orientation of TNB with the coordinated arene. The CT energies can be varied systematically by the choice of appropriate substituents at the coordinated arene. Ferrocene and its derivatives were also observed to form addition compounds with TNB and TCNE [96]. These compounds are also characterized by complex to acceptor CT bands in their electronic spectra.

\section{Donor to Complex CT}

OS donor to complex CT absorptions which do not involve ion pairs have not yet been identified to our knowledge.

\section{Complex to Complex CT}

There is one interesting but rather exotic example which demonstrates the occurance of optical OS CT between neutral complexes. The paramagnetic $\mathrm{d}^{5}$ complex $\mathrm{V}(\mathrm{CO})_{6}$ is deep green-black but only in the solid state. This color was attributed to an OS MMCT transition from one $V^{0}$ to another one [99]. This assumption is supported by the observation that the color disappears upon dissolution. In solution the $\mathrm{V}(\mathrm{CO})_{5}$ molecules are separated from each other and cannot interact electronically. It is of interest that the OS MMCT transition of solid $\mathrm{V}^{0}(\mathrm{CO})_{6}$ generates the mixed-valence ion pair $\left[\mathrm{V}^{\mathrm{I}}(\mathrm{CO})_{6}\right]^{+}\left[\mathrm{V}^{-\mathrm{I}}(\mathrm{CO})_{6}\right]^{-}$which is not stable but undergoes complete back electron transfer. 


\section{Photochemistry}

An optical OS CT transition is an intermolecular photoredox reaction per definition. However, in most cases the primary redox products undergo a rapid back electron transfer which is favored by the large driving force $\Delta \mathrm{E}$ of these systems (Fig. 1). In a few cases the primary products were detected and the kinetics of back electron transfer was determined by flash photolysis. The formation of stable photoproducts depends on the competition between back electron transfer and secondary processes. A permanent chemical change takes place if these secondary processes are faster than back electron transfer. This competition can be influenced by a suitable choice or modification of both redox partners. Back electron transfer will be slowed down by increasing its activation energy $E_{a}^{\prime}$ (Fig. 1). This can be achieved in two ways. $\mathrm{E}_{\mathrm{a}}^{\prime}$ grows with an increasing reorganizational energy which is associated with a larger horizontal displacement of the potential curve of the primary products. Such large structural changes are encountered when the OS CT transition leads to the population or depopulation of bonding or antibonding instead of non-bonding orbitals. $E_{a}^{\prime}$ can also become larger by a decrease of $\Delta \mathrm{E}$ which is associated with a vertical displacement of the potential curves (Fig. 1). However, at the same time the activation energy $E_{a}$ for thermal forward electron transfer is lowered. Thermal electron transfer may now occur and interfere with the light-induced process.

A formation of stable photoproducts depends also on the rate of secondary processes which must compete with back electron transfer. For example, $\mathrm{Co}^{\text {III }}$ amine complexes are well suited as electron acceptors in an irreversible photoreaction since $\mathrm{Co}^{\mathrm{II}}$ amines undergo a very rapid decay [32]. The dynamics of the solvent cage is also important. A certain fraction of the primary electron transfer products may undergo cage escape before back electron transfer takes place. The primary products which escaped from the cage can react to form stable products.

\subsection{Ion Pairs}

\subsubsection{Complex to Complex Charge Transfer}

Photochemical reactions originating from OS LMCT and LLCT excited states are yet unknown. While one example of a reactive OS MLCT state was reported the majority of photoreactions which are induced by OS CT excitation is of the MMCT type.

\section{MLCT}

Upon irradiation $(\lambda=546 \mathrm{~nm})$ of the OS Fe ${ }^{\mathrm{II}}$ to bipy MLCT band the cation of the ion pair $\left[\mathrm{Rh}(\text { bipy })_{3}\right]^{3+}\left[\mathrm{Fe}(\mathrm{CN})_{6}\right]^{4-}$ underwent a photoaquation to $\left[\mathrm{Rh}(\mathrm{bipy})_{2}-\right.$ $\left.\left(\mathrm{H}_{2} \mathrm{O}\right)_{2}\right]^{3+}$ with the quantum yield $\varphi=2.4 \times 10^{-3}[35]$. 
It was suggested that this photoaquation takes place according to the scheme:

$$
\begin{aligned}
& {\left[\mathrm{Rh}^{\mathrm{III}}(\text { bipy })_{3}\right]^{3+}\left[\mathrm{Fe}^{\mathrm{II}}(\mathrm{CN})_{6}\right]^{4-} \stackrel{\text { hv }}{\longrightarrow}} \\
& {\left[\mathrm{Rh}^{\mathrm{III}}(\text { bipy })_{2}\left(\mathrm{bipy}^{-}\right)\right]^{2+}\left[\mathrm{Fe}^{\mathrm{III}}(\mathrm{CN})_{6}\right]^{3-}} \\
& {\left[\mathrm{Rh}(\text { bipy })_{3}\right]^{2+}\left[\mathrm{Fe}(\mathrm{CN})_{6}\right]^{3-} \rightarrow\left[\mathrm{Rh}(\text { bipy })_{3}\right]^{2+}+\left[\mathrm{Fe}(\mathrm{CN})_{6}\right]^{3-}} \\
& {\left[\mathrm{Rh}(\text { bipy })_{3}\right]^{2+} \rightarrow\left[\mathrm{Rh}(\text { bipy })_{2}\right]^{2+}+\text { bpy }} \\
& {\left[\mathrm{Rh}(\text { bipy })_{2}\right]^{2+}+\left[\mathrm{Fe}(\mathrm{CN})_{6}\right]^{3-}+2 \mathrm{H}_{2} \mathrm{O} \rightarrow} \\
& {\left[\mathrm{Rh}(\text { bipy })_{2}\left(\mathrm{H}_{2} \mathrm{O}_{2}\right]^{3+}+\left[\mathrm{Fe}(\mathrm{CN})_{6}\right]^{4-}\right.}
\end{aligned}
$$

The ion pair generated by outer-sphere MLCT excitation may diffuse apart. The third equation describes only the fact that $\left[\mathrm{Rh}(\mathrm{bpy})_{3}\right]^{2+}$ is known to release a bpy ligand. The mechanism of this reaction is not quite clear. Various possibilities, including a disproportionation, are feasible. Finally, electron transfer and subsequent formation of $\left[\mathrm{Rh}(\mathrm{bipy})_{2}\left(\mathrm{H}_{2} \mathrm{O}\right)_{2}\right]^{3-}$ is the last step of this mechanism. The low quantum yield of the overall reaction is probably determined by the rapid thermal reversal of the optical CT transition. This back electron transfer competes with the diffusion step. The ion pairs $\left[\mathrm{Rh}(\text { bipy })_{3}\right]^{3+}\left[\mathrm{M}(\mathrm{CN})_{6}\right]^{4-}$ with $\mathrm{M}=\mathrm{Ru}$, Os seem to be also light-sensitive upon outer-sphere MLCT excitation. However, in this case the CT bands occur at shorter wavelength and thus are overlapping with intramolecular absorption bands of the complexes. For this reason a selective outer-sphere MLCT excitation could not be achieved.

\section{MMCT}

The ion pair $\left[\mathrm{Co}\left(\mathrm{NH}_{3}\right)_{6}\right]^{3+}\left[\mathrm{Ru}(\mathrm{CN})_{6}\right]^{4-}$ in dimethylsulfoxide underwent a photoredox reaction upon $\mathrm{Ru}^{\mathrm{II}}$ to $\mathrm{Co}^{\mathrm{III}} \mathrm{MMCT}$ excitation $\left(\varnothing=0.034\right.$ at $\left.\lambda_{\text {irr }}=366 \mathrm{~nm}\right)$ [41]:

$$
\begin{aligned}
& {\left[\mathrm{Co}^{\mathrm{III}}\left(\mathrm{NH}_{3}\right)_{6}\right]^{3+}\left[\mathrm{Ru}^{\mathrm{II}}(\mathrm{CN})_{6}\right]^{4-} \stackrel{\mathrm{hv}}{\longrightarrow}} \\
& {\left[\mathrm{Co}^{\mathrm{II}}\left(\mathrm{NH}_{3}\right)_{6}\right]^{2+}\left[\mathrm{Ru}^{\mathrm{III}}(\mathrm{CN})_{6}\right]^{3-}} \\
& {\left[\mathrm{Co}^{\mathrm{II}}\left(\mathrm{NH}_{3}\right)_{6}\right]^{2+} \rightarrow \mathrm{Co}^{2+}+6 \mathrm{NH}_{3}}
\end{aligned}
$$

Electron transfer to $\left[\mathrm{Co}\left(\mathrm{NH}_{3}\right)_{6}\right]^{3+}$ requires a large reorganizational energy due to the population of an antibonding $e_{g}$ orbital. As a result the activation energy for back electron transfer $\mathrm{E}_{\mathrm{a}}^{\prime}$ should be also rather large. Moreover, the decomposition of $\left[\mathrm{Co}^{\mathrm{II}}\left(\mathrm{NH}_{3}\right)_{6}\right]^{2+}$ is a rapid process which occurs with a rate constant larger than $10^{6} \mathrm{~s}^{-1}$ [32]. The low quantum yield of $\mathrm{Co}^{2+}$ formation shows, however, that the competition by back electron transfer is still very efficient.

When the ammonia ligands of $\left[\mathrm{Co}\left(\mathrm{NH}_{3}\right]_{6}\right]^{3+}$ are replaced by ethylenediamine (en) and its derivatives (1,2-diaminopropane and 1,2-cyclohexanediamine) the 
$\mathrm{Ru}^{\mathrm{II}}$ to $\mathrm{Co}^{\mathrm{III}} \mathrm{MMCT}$ excitation of the aqueous ion pairs leads to a different result $[12,42]$ :

$$
\begin{aligned}
& {\left[\mathrm{Co}^{\text {III }}(\mathrm{en})_{3}\right]^{3+}\left[\mathrm{Ru}^{\text {II }}(\mathrm{CN})_{6}\right]^{4-} \stackrel{\mathrm{hv}}{\longrightarrow}\left[\mathrm{Co}^{\text {II }}(\mathrm{en})_{3}\right]^{2+}\left[\mathrm{Ru}^{\mathrm{III}}(\mathrm{CN})_{6}\right]^{3-}} \\
& {\left[\mathrm{Co}^{\mathrm{II}}(\mathrm{en})_{3}\right]^{2+}\left[\mathrm{Ru}{ }^{\mathrm{III}}(\mathrm{CN})_{6}\right]^{3-} \stackrel{+\mathrm{H}_{2} \mathrm{O}}{-\mathrm{en}}} \\
& {\left[(\mathrm{en})_{2}\left(\mathrm{H}_{2} \mathrm{O}\right) \mathrm{Co}^{\mathrm{II}}-\mathrm{NC}-\mathrm{Ru}^{\mathrm{III}}(\mathrm{CN})_{5}\right]^{-}} \\
& {\left[(\mathrm{en})_{2}\left(\mathrm{H}_{2} \mathrm{O}\right) \mathrm{Co}^{\mathrm{II}}-\mathrm{NC}-\mathrm{Ru}^{\mathrm{III}}(\mathrm{CN})_{5}\right]^{-} \rightarrow} \\
& {\left[(\mathrm{en})_{2}\left(\mathrm{H}_{2} \mathrm{O}\right) \mathrm{Co}^{\mathrm{III}}-\mathrm{NC}-\mathrm{Ru}^{\mathrm{II}}(\mathrm{CN})_{5}\right]^{-}}
\end{aligned}
$$

The primary reduction product $\left[\mathrm{Co}(\mathrm{en})_{3}\right]^{2+}$ is also substitutionally labile but does not decompose as fast as $\left[\mathrm{Co}\left(\mathrm{NH}_{3}\right)_{6}\right]^{2+}[100,101]$. $\left[\mathrm{Co}(\mathrm{en})_{3}\right]^{2+}$ is then substituted by $\left[\mathrm{Ru}(\mathrm{CN})_{6}\right]^{3-}$. Finally, the thermal electron transfer from $\mathrm{Co}^{\mathrm{II}}$ to $\mathrm{Ru}^{\mathrm{III}}$ by an IS process generates the stable cyanide-bridged complex. The binuclear complex was not isolated but its formation was suggested on the basis of spectral data. The course of this photoreaction is not surprising. It is well known that $\left[\mathrm{Co}^{\mathrm{II}}(\mathrm{CN})_{5}\right]^{3-}$ reacts thermally with $\left[\mathrm{M}^{\mathrm{II}}(\mathrm{CN})_{6}\right]^{4-}(\mathrm{M}=\mathrm{Fe}, \mathrm{Ru}, \mathrm{Os})$ by an IS electron transfer to yield the binuclear complexes $\left[(\mathrm{NC})_{5} \mathrm{Co}^{\mathrm{III}}-\mathrm{NC}-\right.$ $\left.\mathrm{M}^{\mathrm{II}}(\mathrm{CN})_{5}\right]^{6-}[102-104)$.

The aqueous pair $[\mathrm{Co}(\mathrm{sep})]^{3+}\left[\mathrm{Ru}(\mathrm{CN})_{6}\right]^{4-}$ with sep $=$ sepulchrate does not undergo any permanent chemical change upon MMCT excitation since the primary reduction product $[\mathrm{Co}(\mathrm{sep})]^{2+}$ is kinetically stable due to the nature of the cage-type ligand sep $[12,42]$. Back electron transfer is now the only secondary process.

When $\mathrm{Ru}^{\mathrm{II}}$ is replaced by $\mathrm{Fe}^{\mathrm{II}} \Delta \mathrm{E}$ of the ion pair $\left[\mathrm{Co}(\mathrm{en})_{3}\right]^{3+}\left[\mathrm{Fe}(\mathrm{CN})_{6}\right]^{4-}$ becomes smaller by $0.5 \mathrm{~V}$. Consequently, the energy of the MMCT transition (Table 1) as well as the activation energy for thermal electron transfer $\mathrm{E}_{\mathrm{a}}$ decreases. It has been shown indeed that the formation of a binuclear cyanide-bridged complex, most likely $\left[(\mathrm{en})_{2}\left(\mathrm{H}_{2} \mathrm{O}\right) \mathrm{Co}^{\mathrm{III}}-\mathrm{NC}-\mathrm{Fe}^{\mathrm{II}}(\mathrm{CN})_{5}\right]^{-}$, does not only occur as a photochemical but also as a slow thermal reaction [105]. In the presence of excess chloride the photolysis leads to the formation of $\left[\mathrm{Cl}(\mathrm{en})_{2} \mathrm{Co}^{\mathrm{III}} \mathrm{NC}-\mathrm{Fe}^{\mathrm{II}}(\mathrm{CN})_{5}\right]^{2-}$ as a stable product $[106,107]$. The incorporation of chloride into the complex takes certainly place prior to back electron transfer. In this experiment the observation of an OS MMCT absorption was not reported. It was suggested that the reaction could originate from a OS MMCT state which might have been populated from a ligand field excited state of $\left[\mathrm{Co}(\mathrm{en})_{3}\right]^{3+}$.

Octahedral ammine complexes of the $\mathrm{d}^{5}$ metals $\mathrm{Ru}^{\mathrm{III}}$ and $\mathrm{Os}^{\mathrm{III}}$ can also serve as electron acceptors. However, in distinction to the $\mathrm{d}^{6}$ metal $\mathrm{Co}^{\mathrm{III}}$ the reduction of $\mathrm{Ru}^{\mathrm{III}}$ and $\mathrm{Os}^{\mathrm{III}}$ by $\mathrm{CT}$ excitation does not require a large reorganizational energy since the acceptor orbitals $\left(t_{2 g}\right)$ are non-bonding. Their population has thus not a large effect on the metal-ligand distance. The activation energy for back electron transfer is presumably rather small. In addition, ammine complexes of $\mathrm{Ru}^{\mathrm{II}}$ and $\mathrm{Os}^{\mathrm{II}}$ as primary reduction products are less labile than the ammine complexes of $\mathrm{Co}^{\mathrm{II}}$. For these reasons the ion pairs $\left[\mathrm{M}^{\mathrm{III}}\left(\mathrm{NH}_{3}\right)_{5} \mathrm{~L}\right]^{\mathrm{n}+}\left[\mathrm{M}^{\mathrm{II}}(\mathrm{CN})_{5}\right]^{4-}$ with $\mathrm{M}^{\mathrm{III}}=$ $\mathrm{Ru}^{\mathrm{III}}, \mathrm{Os}^{\mathrm{III}}$ and $\mathrm{M}^{\mathrm{II}}=\mathrm{Fe}^{\mathrm{II}}, \mathrm{Ru}^{\mathrm{II}}$, Os ${ }^{\mathrm{II}}$ are not expected to undergo an efficient 
formation of stable products upon OS MMCT excitation. Generally, this expectation has been confirmed but in some cases a photoactivity was observed.

The aqueous homonuclear ion pair $\left[\mathrm{Ru}^{\mathrm{III}}\left(\mathrm{NH}_{3}\right)_{5} \mathrm{Cl}\right]^{2+}\left[\mathrm{Ru}^{\mathrm{II}}(\mathrm{CN})_{6}\right]^{4-}$ underwent a photolysis upon MMCT excitation at $\lambda=546 \mathrm{~nm}$ with $\varphi=0.002$ [47]. The reaction proceeds according to the following scheme:

$$
\begin{aligned}
& {\left[\mathrm{Ru}^{\mathrm{III}}\left(\mathrm{NH}_{3}\right)_{5} \mathrm{Cl}\right]^{2+}\left[\mathrm{Ru}^{\mathrm{II}}(\mathrm{CN})_{6}\right]^{4-} \stackrel{\mathrm{hv}}{\rightarrow}\left[\mathrm{Ru}^{\mathrm{II}}\left(\mathrm{NH}_{3}\right)_{5} \mathrm{Cl}\right]^{+}\left[\mathrm{Ru}^{\mathrm{III}}(\mathrm{CN})_{6}\right]^{3-}} \\
& {\left[\mathrm{Ru}^{\mathrm{II}}\left(\mathrm{NH}_{3}\right)_{5} \mathrm{Cl}\right]^{+}\left[\mathrm{Ru}^{\mathrm{III}}(\mathrm{CN})_{6}\right]^{3-} \rightarrow} \\
& {\left[\mathrm{Ru}^{\mathrm{II}}\left(\mathrm{NH}_{3}\right)_{5} \mathrm{Cl}\right]^{+}+\left[\mathrm{Ru}^{\mathrm{III}}(\mathrm{CN})_{6}\right]^{3-}} \\
& {\left[\mathrm{Ru}^{\mathrm{II}}\left(\mathrm{NH}_{3}\right)_{5} \mathrm{Cl}\right]^{+}+\mathrm{H}_{2} \mathrm{O} \rightarrow\left[\mathrm{Ru}^{\mathrm{II}}\left(\mathrm{NH}_{3}\right)_{5}\left(\mathrm{H}_{2} \mathrm{O}\right)\right]^{2+}+\mathrm{Cl}^{-}} \\
& {\left[\mathrm{Ru}^{\mathrm{II}}\left(\mathrm{NH}_{3}\right)_{5} \mathrm{H}_{2} \mathrm{O}\right]^{2+}+\left[\mathrm{Ru}^{\mathrm{II}}(\mathrm{CN})_{6}\right]^{4-} \rightarrow} \\
& {\left[\left(\mathrm{NH}_{3}\right)_{5} \mathrm{Ru}^{\mathrm{II}}-\mathrm{NC}-\mathrm{Ru}^{\mathrm{II}}(\mathrm{CN})_{5}\right]^{2-}} \\
& {\left[\left(\mathrm{NH}_{3}\right)_{5} \mathrm{Ru}^{\mathrm{II}}-\mathrm{NC}-\mathrm{Ru}^{\mathrm{II}}(\mathrm{CN})_{5}\right]^{2-}+\left[\mathrm{Ru}^{\mathrm{III}}(\mathrm{CN})_{6}\right]^{3-} \rightarrow} \\
& {\left[\left(\mathrm{NH}_{3}\right)_{5} \mathrm{Ru}^{\mathrm{III}}-\mathrm{NC}-\mathrm{Ru}^{\mathrm{II}}(\mathrm{CN})_{5}\right]^{-}+\left[\mathrm{Ru}^{\mathrm{II}}(\mathrm{CN})_{6}\right]^{4-}}
\end{aligned}
$$

The ion pair, generated by MMCT excitation may diffuse apart. $\left[\mathrm{Ru}^{\mathrm{II}}\left(\mathrm{NH}_{3}\right)_{5} \mathrm{Cl}\right]^{+}$ aquates rapidly with $\mathrm{k}=5 \mathrm{~s}^{-1}$. Substitutionally labile $\left[\mathrm{Ru}^{\mathrm{II}}\left(\mathrm{NH}_{3}\right)_{5} \mathrm{H}_{2} \mathrm{O}\right]^{2+}$ reacts with $\left[\mathrm{Ru}(\mathrm{CN})_{6}\right]^{4-}$ which is present in large excess. The formation of the binuclear complex is certainly facilitated by the high opposite charges of the reacting ions. Finally, electron transfer restores ruthenium to its stable oxidation states. The low quantum yield of the overall reaction is most likely determined by the extremely rapid thermal reversal of the MMCT transition, which competes with the diffusion apart from the primary electron transfer products. Product formation occurs also thermally indicating a small activation energy $(\sim 22 \mathrm{kcal} /$ mol) for thermal electron transfer.

The aqueous ion pairs $\left[\mathrm{Os}^{\mathrm{III}}\left(\mathrm{NH}_{3}\right)_{5} \mathrm{Cl}\right]^{2+}\left[\mathrm{M}^{\mathrm{II}}(\mathrm{CN})_{6}\right]^{4-}$ with $\mathrm{M}=\mathrm{Fe}, \mathrm{Ru}$ and $\mathrm{Os}$ undergo photoreactions which are quite analogous to that of $\left[\mathrm{Ru}^{\mathrm{III}}\left(\mathrm{NH}_{3}\right)_{5} \mathrm{Cl}\right]^{2+}$. $\left[\mathrm{Ru}^{\mathrm{II}}(\mathrm{CN})_{6}\right]^{4-}$. Upon $\mathrm{M}^{\mathrm{II}}$ to Os ${ }^{\mathrm{III}}$ MMCT excitation $\left(\lambda_{\text {irr }}=405 \mathrm{~nm}\right)$ the binuclear complexes $\left[\left(\mathrm{NH}_{3}\right)_{5} \mathrm{Os}{ }^{\mathrm{III}}-\mathrm{NC}-\mathrm{M}^{\mathrm{II}}(\mathrm{CN})_{5}\right]^{-}$are formed $[12,42]$. The quantum yields $(\varphi=0.12$ for $\mathrm{M}=\mathrm{Fe}, 0.04$ for $\mathrm{Ru}$ and $\mathrm{Os})$ are larger than that of the $\mathrm{Ru}^{\mathrm{II}} / \mathrm{Ru}^{\mathrm{III}}$ ion pair.

OS $\mathrm{Fe}^{\mathrm{II}}$ to $\mathrm{Ru}^{\mathrm{III}} \mathrm{MMCT}$ excitation $\left(\lambda_{\text {irr }}=1060 \mathrm{~nm}\right)$ of the aqueous ion pair $\left[\mathrm{Ru}^{\mathrm{III}}\left(\mathrm{NH}_{3}\right)_{5}(\mathrm{py})\right]^{3+}\left[\mathrm{Fe}^{\mathrm{II}}(\mathrm{CN})_{6}\right]^{4-}$ with py $=$ pyridine does not yield stable products. However, flash photolysis revealed some interesting details of the reversible photoreaction $[40,108]$. The Franck-Condon excited MMCT state $\left[\mathrm{Ru}^{\mathrm{II}}\left(\mathrm{NH}_{3}\right)_{5}{ }^{-}\right.$ py $]^{2+}\left[\mathrm{Fe}^{\mathrm{III}}(\mathrm{CN})_{6}\right]^{3-}$ does not undergo a vibrational relaxation with unit efficiency but returns partially to the $\mathrm{Ru}^{\mathrm{III}} / \mathrm{Fe}^{\mathrm{III}}$ ground state. The equilibrated $\mathrm{Ru} / \mathrm{Fe}^{\mathrm{III}}$ MMCT state undergoes also a back electron transfer and a competing cage escape. Finally, the separated ions $\left[\mathrm{Ru}^{\mathrm{II}}\left(\mathrm{NH}_{3}\right)_{5} \mathrm{py}\right]^{2+}$ and $\left[\mathrm{Fe}^{\mathrm{III}}(\mathrm{CN})_{6}\right]^{3-}$ regenerate the ion pair. Back electron transfer in this ion pair restores the stable oxidation states. 


\section{Organometallic Ion Pairs}

Many salts consisting of an oxidizing metal carbonyl cation and a reducing metal carbonyl anion were prepared and characterized. They are expected to display long-wavelength OS MMCT absorptions. This was confirmed for the ion pair $\left[\mathrm{Co}(\mathrm{CO})_{3}\left(\mathrm{PPh}_{3}\right)_{2}\right]^{+}\left[\mathrm{Co}(\mathrm{CO})_{4}\right]^{-}$[54] (Table 2). The photochemistry of this ion pair is rather complicated upon short-wavelength irradiation which leads to the excitation of the cation [109]. When the light is absorbed by the MMCT band at longer wavelength $\left(\lambda_{\text {irr }}=405 \mathrm{~nm}\right)$ a radical pair is formed. The processes which are initiated by the MMCT transition can be explained by the following mechanism [54]:

$$
\begin{aligned}
& {\left[\mathrm{Co}^{+\mathrm{I}}(\mathrm{CO})_{3}\left(\mathrm{PPh}_{3}\right)_{2}\right]^{+}\left[\mathrm{Co}^{-1}(\mathrm{CO})_{4}\right]^{-} \stackrel{\mathrm{hv}}{\longrightarrow}} \\
& {\left[\mathrm{Co}^{0}(\mathrm{CO})_{3}\left(\mathrm{PPh}_{3}\right)_{2}\right]\left[\mathrm{Co}^{0}(\mathrm{CO})_{4}\right]} \\
& {\left[\mathrm{Co}^{+\mathrm{I}}(\mathrm{CO})_{3}\left(\mathrm{PPh}_{3}\right)_{2}\right]\left[\mathrm{Co}^{0}(\mathrm{CO})_{4}\right] \rightarrow\left[\mathrm{Co}^{0}(\mathrm{CO})_{3}\left(\mathrm{PPh}_{3}\right)_{2}\right]+\left[\mathrm{Co}^{0}(\mathrm{CO})_{4}\right]} \\
& {\left[\mathrm{Co}^{0}(\mathrm{CO})_{3}\left(\mathrm{PPh}_{3}\right)_{2}\right] \rightarrow\left[\mathrm{Co}^{0}(\mathrm{CO})_{3}\left(\mathrm{PPh}_{3}\right)\right]+\mathrm{PPh}_{3}} \\
& {\left[\mathrm{Co}^{0}(\mathrm{CO})_{4}+\mathrm{PPh}_{3} \rightarrow\left[\mathrm{Co}^{0}(\mathrm{CO})_{3} \mathrm{PPh}_{3}\right]+\mathrm{CO}\right.} \\
& 2\left[\mathrm{Co}^{0}(\mathrm{CO})_{3}\left(\mathrm{PPh}_{3}\right) \rightarrow\left[\left(\mathrm{PPh}_{3}\right)(\mathrm{CO})_{3} \mathrm{Co}-\mathrm{Co}(\mathrm{CO})_{3}\left(\mathrm{PPh}_{3}\right)\right]\right.
\end{aligned}
$$

The primary radicals may diffuse apart. These radicals are certainly labile toward substitution or dissociation. Finally, the radical $\left[\mathrm{Co}(\mathrm{CO})_{3}\left(\mathrm{PPh}_{3}\right)\right]$ is formed which dimerizes to the product. The low quantum yield of the photoreaction $(\varphi=0.012)$ may be due to a competing reversal of some of these processes including back electron transfer within the primary radical pair. It is quite interesting that product formation occurs also thermally at elevated temperatures [110]. This indicates a relatively low activation energy $\mathrm{E}_{\mathrm{a}}$ (Fig. 1). In this context it is rather important to pay attention to the general significance of this thermal reaction in organometallic chemistry [51]. With regard to the photochemistry we would like to emphasize the relationship between the light-induced formation and homolytic cleavage of metal-metal bonds:

$$
\begin{aligned}
& {\left[\mathrm{M}^{+\mathrm{I}}(\mathrm{CO})_{\mathrm{n}} \mathrm{L}\right]^{+}\left[\mathrm{M}^{-1}(\mathrm{CO})_{\mathrm{n}}\right] \stackrel{\text { MMCT }}{\rightleftarrows} 2\left[\cdot \mathrm{M}^{0}(\mathrm{CO})_{\mathrm{n}}\right]+\mathrm{L} \stackrel{\sigma \sigma *}{\leftrightarrows}} \\
& {\left[(\mathrm{OC})_{\mathrm{n}} \mathrm{M}^{0}-\mathrm{M}^{0}(\mathrm{CO})_{\mathrm{n}}\right]+\mathrm{L}}
\end{aligned}
$$

Both photoreactions, electron transfer by MMCT excitation and metal-metal bond splitting by $\sigma \sigma^{*}$ excitation $[19,111,112]$, generate the same or similar radicals.

Instead of metal carbonyl cations, oxidizing metallocenium cations can be also used as electron acceptors. Upon MMCT excitation $\left(\lambda_{\text {irr }}>520 \mathrm{~nm}\right)$ of $\left[\mathrm{Co}^{\mathrm{III}}\left(\mathrm{C}_{5} \mathrm{H}_{5}\right)_{2}{ }^{+}\left[\mathrm{Co}^{-\mathrm{I}}(\mathrm{CO})_{4}\right]^{-}\right.$in THF, cobaltocene and $\left[\mathrm{Co}(\mathrm{CO})_{4}\right]$ are formed as a radical pair which undergoes a rapid back electron transfer to the starting ion 
pair [59]. In the presence of phosphites the formation of stable products takes place.

$$
\begin{aligned}
& {\left[\mathrm{Co}^{\mathrm{III}}\left(\mathrm{C}_{5} \mathrm{H}_{5}\right)_{2}\right]^{+}\left[\mathrm{Co}^{-1}(\mathrm{CO})_{4}\right]^{-} \stackrel{\mathrm{hv}}{\longrightarrow}\left[\mathrm{Co}^{\mathrm{II}}\left(\mathrm{C}_{5} \mathrm{H}_{5}\right)_{2}\right]\left[\mathrm{Co}^{0}(\mathrm{CO})_{4}\right]} \\
& {\left[\mathrm{Co}^{\mathrm{II}}\left(\mathrm{C}_{5} \mathrm{H}_{5}\right)_{2}\right]^{+}\left[\mathrm{Co}^{0}(\mathrm{CO})_{4}\right] \rightarrow\left[\mathrm{Co}^{\mathrm{II}}\left(\mathrm{C}_{5} \mathrm{H}_{5}\right)\right]+\left[\mathrm{Co}^{0}(\mathrm{CO})_{4}\right]} \\
& {\left[\mathrm{Co}^{0}(\mathrm{CO})_{4}\right]+\mathrm{P}(\mathrm{OR})_{3} \rightarrow\left[\mathrm{Co}^{0}(\mathrm{CO})_{3} \mathrm{P}(\mathrm{OR})_{3}\right]+\mathrm{CO}} \\
& {\left[\mathrm{Co}^{\mathrm{II}}\left(\mathrm{C}_{5} \mathrm{H}_{5}\right)_{2}\right]+\left[\mathrm{Co}^{0}(\mathrm{CO})_{3} \mathrm{P}(\mathrm{OR})_{3} \rightarrow\right.} \\
& {\left[\mathrm{Co}^{\mathrm{III}}\left(\mathrm{C}_{5} \mathrm{H}_{5}\right)_{2}\right]^{+}\left[\mathrm{Co}^{-\mathrm{I}}(\mathrm{CO})_{3} \mathrm{P}(\mathrm{OR})_{3}\right]^{-}}
\end{aligned}
$$

The $\left[\mathrm{Co}(\mathrm{CO})_{4}\right]$ radicals which escape the primary radical pair are substituted before back electron transfer occurs. In the presence of phosphines the reaction takes a different course :

$$
\begin{aligned}
& {\left[\mathrm{Co}^{\mathrm{III}}\left(\mathrm{C}_{5} \mathrm{H}_{5}\right)_{2}\right]^{+}\left[\mathrm{Co}^{-1}(\mathrm{CO})_{4}\right]^{-}+\mathrm{PR}_{3} \stackrel{\mathrm{hv}}{\longrightarrow}} \\
& {\left[\mathrm{Co}^{\mathrm{II}}\left(\mathrm{C}_{5} \mathrm{H}_{5}\right)_{2}\right]+1 / 2\left[\mathrm{Co}_{2}^{0}(\mathrm{CO})_{6}\left(\mathrm{PR}_{3}\right)_{2}\right]}
\end{aligned}
$$

The dimerization of the substituted radical $\left[\mathrm{Co}(\mathrm{CO})_{3} \mathrm{PR}_{3}\right]$ is now apparently faster than back electron transfer.

Upon MMCT excitation $\left(\lambda_{\text {irr }}>580 \mathrm{~nm}\right)$ the ion pair $\left[\mathrm{Co}^{\mathrm{II}}\left(\mathrm{C}_{5} \mathrm{H}_{5}\right)_{2}\right]^{+}\left[\mathrm{Mn}^{-\mathrm{I}}-\right.$ $\left.(\mathrm{CO})_{5}\right]^{-}$undergoes an analogous photoreaction in the absence of an entering ligand [60]:

$$
\left[\mathrm{Co}^{\mathrm{III}}\left(\mathrm{C}_{5} \mathrm{H}_{5}\right)_{2}\right]^{+}\left[\mathrm{Co}^{-1}(\mathrm{CO})_{4}\right]^{-} \stackrel{\mathrm{hv}}{\longrightarrow}\left[\mathrm{Co}^{\mathrm{Il}}\left(\mathrm{C}_{5} \mathrm{H}_{5}\right)_{2}\right]+1 / 2\left[\mathrm{Mn}_{2}^{0}(\mathrm{CO})_{10}\right]
$$

It is quite surprising that this photoreaction proceeds in a $\mathrm{KBr}$ matrix since the mobility and hence the cage escape of $\left[\mathrm{Mn}(\mathrm{CO})_{5}\right]$ radicals should be hindered in this medium.

The ion pair $\left[\mathrm{Co}\left(\mathrm{C}_{5} \mathrm{H}_{5}\right)_{2}\right]^{+}\left[\mathrm{Mn}(\mathrm{CO})_{5}\right]^{-}$is thermally rather stable in distinction to $\left[\mathrm{Cr}\left(\mathrm{C}_{6} \mathrm{H}_{6}\right)_{2}\right]^{+}\left[\mathrm{Mn}(\mathrm{CO})_{5}\right]^{-}$which undergoes the electron transfer under ambient conditions $[58,60]$ :

$$
\left[\mathrm{Cr}^{\mathrm{I}}\left(\mathrm{C}_{6} \mathrm{H}_{6}\right)_{2}\right]^{+}\left[\mathrm{Mn}^{-1}(\mathrm{CO})_{5}\right]^{-} \rightarrow\left[\mathrm{Cr}^{0}\left(\mathrm{C}_{6} \mathrm{H}_{6}\right)_{2}\right]+1 / 2\left[\mathrm{Mn}_{2}^{0}(\mathrm{CO})_{10}\right]
$$

This different behavior is quite unexpected since the potentials of the redox couples $\left[\mathrm{Co}\left(\mathrm{C}_{5} \mathrm{H}_{5}\right)_{2}\right]^{+/ 0}$ and $\left[\mathrm{Cr}\left(\mathrm{C}_{6} \mathrm{H}_{6}\right)_{2}\right]^{+/ 0}$ and consequently $\Delta \mathrm{E}$ of both ion pairs are very similar. However, the cation $\left[\mathrm{Cr}^{\mathrm{I}}\left(\mathrm{C}_{6} \mathrm{H}_{6}\right)_{2}\right]^{+}$which contains a d $\mathrm{d}^{5}$ metal accepts the electron in a non-bonding $a_{1 g}$ orbital. This is associated with a rather small reorganizational energy and therefore also low activation energy for thermal electron transfer. On the contrary, $\left[\mathrm{Co}\left(\mathrm{C}_{5} \mathrm{H}_{5}\right)_{2}\right]^{+}$with a d $\mathrm{d}^{6}$ metal must accept the electron into an antibonding $e_{1 g}$ orbital which requires a much larger reorganizational and activation energy. 


\subsubsection{Ion Pairs Consisting of a Complex and a Non-metallic Counter Ion}

\section{Complex to Acceptor CT}

The majority of ion pairs which are composed of an organic cation as acceptor and a metal complex anion as donor have not been observed to be light sensitive upon OS CT exciation. Secondary reactions of the primary redox products are apparently too slow to compete with back electron transfer which restores the starting ion pair. Kinetic data were obtained for the ion pair 1,1'-dimethyl-4,4'bipyridinium $\left.^{2+}[\mathrm{Zn} \text { (maleonitriledithiolate) })_{2}\right]^{2-}[72]$. OS CT excitation of the ion pair leads to an electron transfer from the coordinated ligand to the cation. The primary photoproduct $1,1^{\prime}$-dimethyl-4,4'-bipyridinium ${ }^{+}[\mathrm{Zn}$ (maleonitriledithiolate $\left.)_{2}\right]^{-}$was detected by flash photolysis. It regenerates the starting ion pair by back electron transfer with the second order rate constant $\mathrm{k}=3.6 \times 10^{9} \mathrm{M}^{-1} \mathrm{~s}^{-1}$.

When $\mathrm{Ph}_{2} \mathrm{I}^{+}$and $\mathrm{RN}_{2}^{+}$are used as acceptors an OS CT excitation results in a permanent chemical change since these cations undergo an irreversible reduction. The decay of the radicals $\mathrm{Ph}_{2} \mathrm{I} \cdot$ and $\mathrm{R}-\mathrm{N}_{2} \cdot$ is apparently a very rapid process which competes successfully with their reoxidation.

Hennig and his group investigated the photochemistry of nonaqueous solutions of ion pairs which consist of the diphenyliodonium cation as acceptor and the cyano complexes $\left[\mathrm{Fe}^{\mathrm{II}}(\mathrm{CN})_{5} \mathrm{DMSO}^{3-},\left[\mathrm{Ru}^{\mathrm{II}}(\mathrm{CN})_{6}\right]^{4-},\left[\mathrm{Mo}^{\mathrm{IV}}(\mathrm{CN})_{8}\right]^{4-},\left[\mathrm{W}^{\mathrm{IV}}-\right.\right.$ $\left.(\mathrm{CN})_{8}\right]^{4-}$, and $\left[\mathrm{Mn}^{\mathrm{I}}(\mathrm{CN})_{5} \mathrm{NO}\right]^{3-}$ as donors $[64,65]$. As an example, upon OS complex to acceptor CT excitation $\left(\lambda_{\text {irr }}=475\right)$ the ion pair $\mathrm{Ph}_{2} \mathrm{I}^{+}\left[\mathrm{Mo}(\mathrm{CN})_{8}\right]^{4-}$ reacts according to the following equations:

$$
\begin{aligned}
& \mathrm{Ph}_{2} \mathrm{I}^{+}\left[\mathrm{Mo}^{\mathrm{IV}}(\mathrm{CN})_{8}\right]^{4-} \stackrel{\mathrm{hv}}{\longrightarrow} \mathrm{Ph}_{2} \mathrm{I} \cdot+\left[\mathrm{Mo}^{\mathrm{v}}(\mathrm{CN})_{8}\right]^{3-} \\
& \mathrm{Ph}_{2} \mathrm{I} \cdot \rightarrow \mathrm{Ph}-\mathrm{I}+\mathrm{Ph} .
\end{aligned}
$$

The diphenyliodonium radical decomposes to iodobenzene and a phenyl radical which undergoes further reactions. The other ion pairs undergo the same type of reaction. The quantum yields are rather high $(0.3$ to 0.8$)]$

Arenediazonium cations are reduced thermally by $\left[\mathrm{Fe}(\mathrm{CN})_{6}\right]^{4-}$ in aqueous solution at room temperature [113]. The irreversible reduction yields $\mathrm{N}_{2}$ and phenyl radicals. The slowest electron transfer was observed with the $p$-methoxybenzenediazonium cation $\left(\mathrm{k}=0.71 \mathrm{M}^{-1} \mathrm{~s}^{-1}\right)$. Unfortunately, due to their thermal instability the ion pairs $\mathrm{R}-\mathrm{C}_{6} \mathrm{H}_{4}-\mathrm{N}_{2}^{+}\left[\mathrm{Fe}(\mathrm{CN})_{6}\right]^{4-}$ are not well suited to study their electronic spectra and photoreactions. However, much more stable ion pairs should be formed if $\left[\mathrm{Fe}(\mathrm{CN})_{6}\right]^{4-}$ is replaced by the less reducing anion $\left[\mathrm{Ru}(\mathrm{CN})_{6}\right]^{4-}$. The ion pair $p-\mathrm{CH}_{3} \mathrm{O}-\mathrm{C}_{6} \mathrm{H}_{4}-\mathrm{N}_{2}^{+}\left[\mathrm{Ru}(\mathrm{CN})_{6}\right]^{4-}$ is indeed rather stable but undergoes an irreversible photoreaction upon OS CT excitation $\left(\lambda_{\text {irr }}=405 \mathrm{~nm}\right)[66] .\left[\mathrm{Ru}(\mathrm{CN})_{6}\right]^{3-}$ was formed with the quantum yield $\varphi=0.02$. 
It is suggested that the photolysis proceed according to the equation:

$$
\begin{aligned}
& \mathrm{CH}_{3} \mathrm{O}-\mathrm{C}_{6} \mathrm{H}_{4}-\mathrm{N}_{2}^{+}\left[\mathrm{Ru}^{\mathrm{II}}(\mathrm{CN})_{6}\right]^{4-} \stackrel{\mathrm{hv}}{\longrightarrow} \\
& \mathrm{CH}_{3} \mathrm{O}-\mathrm{C}_{6} \mathrm{H}_{4} \mathrm{~N}_{2}\left[\mathrm{Ru}^{\mathrm{III}}(\mathrm{CN})_{6}\right]^{3-} \\
& \mathrm{CH}_{3} \mathrm{O}-\mathrm{C}_{6} \mathrm{H}_{4} \mathrm{~N}_{2} \rightarrow \mathrm{CH}_{3} \mathrm{O}-\mathrm{C}_{6} \mathrm{H}_{4} \cdot+\mathrm{N}_{2}
\end{aligned}
$$

The fate of the $p$-methoxyphenyl radical was not investigated.

\section{Donor to Complex CT}

A number of studies on the photochemistry of ion pairs of the type $\left[\mathrm{M}^{\mathrm{III}}\left(\mathrm{NH}_{3}\right)_{5} \mathrm{~L}\right]^{\mathrm{n}+}$ $\mathrm{X}^{-}$with $\mathrm{M}=\mathrm{Co}, \mathrm{Ru}$ and $\mathrm{X}=$ halide and other anions has been carried out. Ford and his group investigated the photolysis of $\mathrm{Ru}^{\mathrm{III}}$ ammines following $\mathrm{X}^{-}$ to $\mathrm{Ru}^{\mathrm{III}}$ OS CT excitation [83]. These ion pairs are not expected to be particularly light-sensitive upon OS CT excitation since the primary reduction product $\left[\mathrm{Ru}^{\mathrm{II}}\left(\mathrm{NH}_{3}\right)_{5} \mathrm{~L}\right]^{+(\mathrm{n}-1)}$ is fairly stable. Back electron transfer may be then much faster than any other secondary reaction. Generally, this expectation was confirmed. The flash photolysis of $\left[\mathrm{Ru}^{\text {III }}\left(\mathrm{NH}_{3}\right)_{5} \text { pyridine }\right]^{3+} \mathrm{Cl}^{-}$did not even yield any transient indicating an extremely rapid regeneration of the starting ion pair. When $\mathrm{X}^{-}$was $\mathrm{Br}^{-}$or $\mathrm{I}^{-}$the formation of $\mathrm{Ru}^{\mathrm{II}}$ intermediates was observed. However, back electron transfer was still very fast. With $\mathrm{X}=\mathrm{I}$ a low-yield photosubstitution took place upon continuous irradiation of the OS CT band. In the case of the ion pair $\left[\mathrm{Ru}^{\mathrm{III}}\left(\mathrm{NH}_{3}\right)_{5}\right]^{3+} \mathrm{C}_{2} \mathrm{O}_{4}^{2-}$ an efficient irreversible photoreduction to $\left[\mathrm{Ru}^{\mathrm{II}}\left(\mathrm{NH}_{3}\right)_{5} \text { pyridine }\right]^{2+}$ took place $\left(\varphi=0.35\right.$ at $\left.\lambda_{\text {irr }}=405 \mathrm{~nm}\right)$. This is certainly due to the rapid decay of the oxidized oxalate.

When $\mathrm{Co}^{\mathrm{III}}$ ammines are used as acceptors OS CT excitation is generally associated with a permanent reduction to $\mathrm{Co}^{\mathrm{III}}$ (see 4.1.1). Historically, the first study on a photoreaction of a metal complex induced by OS CT excitation was carried out by Adamson and Sporer in 1958 [114]. They found that light absorption by an $\mathrm{OS}\left(\mathrm{I}^{-}\right.$to $\left.\mathrm{Co}^{\mathrm{III}}\right) \mathrm{CT}$ bad of the aqueous ion pair $\left[\mathrm{Co}\left(\mathrm{NH}_{3}\right)_{6}\right]^{3+} \mathrm{I}^{-}$led to a redox decomposition $\left(\varphi=0.77\right.$ at $\left.\lambda_{\mathrm{irr}}=370 \mathrm{~nm}\right)$. The photolysis may proceed according the following equation:

$$
\left[\mathrm{Co}{ }^{\mathrm{III}}\left(\mathrm{NH}_{3}\right)_{6}\right]^{3+} \mathrm{I}^{-} \stackrel{\mathrm{hv}}{\longrightarrow}\left[\mathrm{Co}^{\mathrm{II}}\left(\mathrm{NH}_{3}\right)_{6}\right]^{2+} \mathrm{I} \rightarrow \mathrm{Co}^{2+}+6 \mathrm{NH}_{3}+1 / 2 \mathrm{I}_{2}
$$

An analogous photoreaction of $\left[\mathrm{Co}\left(\mathrm{NH}_{3}\right)_{6}\right]^{3+}\left(\mathrm{BPh}_{4}\right)^{-}$was investigated by Hannig and his group $[115,116]$. In this case the formation of stable redox products upon OS CT excitation is not only favored by the facile decay of $\left[\mathrm{Co}\left(\mathrm{NH}_{3}\right)_{6}\right]^{2+}$ but also by an efficient irreversible decomposition of the $\mathrm{BPh}_{4}$ radicals which split off phenyl radicals. Essentially the same behavior is shown by the ion pairs $\left[\mathrm{Co}^{\mathrm{III}}\left(\mathrm{NH}_{3}\right)_{5} \mathrm{Y}^{2+} \mathrm{X}^{-}\right.$with $\mathrm{Y}^{-}=\mathrm{CH}_{3} \mathrm{COO}^{-}, \mathrm{NO}_{2}^{-}, \mathrm{Br}^{-}, \mathrm{Cl}^{-}$, $\mathrm{F}^{-}, \mathrm{N}_{3}^{-}$, and $\mathrm{NO}_{3}^{-}$and $\mathrm{X}^{-}=\mathrm{BPh}_{4}^{-}$and $\mathrm{I}^{-}$.

When $\left[\mathrm{Co}\left(\mathrm{NH}_{3}\right)_{6}\right]^{3+}$ is replaced by $\left[\mathrm{Co}(\mathrm{en})_{3}\right]^{3+}$ an $\mathrm{OS} \mathrm{X}^{-}$to $\mathrm{Co}^{\mathrm{III}} \mathrm{CT}$ excitation may not be expected to lead to an efficient production of $\mathrm{Co}^{\mathrm{III}}$ since $\left[\mathrm{Co}^{\mathrm{II}}(\mathrm{en})_{3}\right]^{2+}$ decays much slower than $\left[\mathrm{Co}^{\mathrm{II}}\left(\mathrm{NH}_{3}\right)_{6}\right]^{2+}[100,101]$ (see above). However, if $\mathrm{X}^{-}$ 
undergoes an oxidative decomposition the production of $\mathrm{Co}^{2+}$ can still take place with high quantum yields. For example, $\mathrm{Co}^{2+}$ is formed with $\varphi=0.13$ $\left(\lambda_{\text {irr }}=313 \mathrm{~nm}\right)$ upon OS CT excitation of $\left[\mathrm{Co}(\mathrm{en})_{3}\right]^{3+} \mathrm{HC}_{2} \mathrm{O}_{4}^{-}$[80]. The ion pair $\left[\mathrm{Co}(\mathrm{en})_{3}\right]^{3+} \mathrm{htc}^{-}$with htc ${ }^{-}=$bis(2-hydroxyethyl)dithiocarbarmate undergoes the same type of photoredox reaction [117]. In the presence of an excess of htc $\mathrm{Co}^{2+}$ forms a stable complex with this ligand. This $\mathrm{Co}^{\text {II } h t c}$ complex is now able to reduce $\left[\mathrm{Co}(\mathrm{en})_{3}\right]^{3+}$ thermally.

Consequently a chain reaction occurs and the observed quantum yield for $\mathrm{Co}^{2+}$ production can exceed unity. Analogous photoreactions were found for the ion pairs of $\left[\mathrm{Co}\left(\mathrm{NH}_{3}\right)_{6}\right]^{3+},\left[\mathrm{Co}\left(\mathrm{NH}_{3}\right)_{4}(1,2 \text {-propanediamine })\right]^{3+},[\mathrm{Co}(1,2$-cyclohexanediamine $\left.)_{3}\right]^{3+}$ and $\left[\mathrm{Co}(\text { diethylenetriamine })_{2}\right]^{3+}$ with $\mathrm{htc}^{-}$as counter ion.

The acceptor cation $\left[\mathrm{Co}^{\text {III }}(\mathrm{sep})\right]^{3+}$ does not undergo an irreversible reduction since the $\mathrm{Co}^{\mathrm{II}}$ complex is kinetically stable due to the cage-type nature of the sepulchrate ligand. It is then not surprising that in deoxygenated, neutral solutions OS CT excitation $\left(\lambda_{\text {irr }}=313 \mathrm{~nm}\right)$ of $[\mathrm{Co}(\mathrm{sep})]^{3+} \mathrm{I}^{-}$does not lead to any permanent chemical change. The primary redox product $\left[\mathrm{Co}^{\mathrm{II}}(\mathrm{sep})\right]^{2+}$ and iodine simply regenerate the starting ion pair $[78,79]$. However, in acidic medium $[\mathrm{Co}(\mathrm{sep})]^{2+}$ is not any more stable. The decomposition competes now with its reoxidation by iodine. As a result $\mathrm{Co}^{2+}$ and $\mathrm{I}_{2}$ are produced although with small quantum yields. In the presence of air $[\mathrm{Co}(\mathrm{sep})]^{2+}$ can be intercepted by $\mathrm{O}_{2}$. In this case $[\mathrm{Co}(\mathrm{sep})]^{3+}$ acts as a sensitizer for the photoassisted oxidation of iodide by $\mathrm{O}_{2}$ :

$$
4 \mathrm{I}^{-}+\mathrm{O}_{2}+4 \mathrm{H}^{+} \rightarrow 2 \mathrm{I}_{2}+2 \mathrm{H}_{2} \mathrm{O}
$$

If deoxygenated solutions of $[\mathrm{Co}(\mathrm{sep})]^{3+} \mathrm{X}^{-}$with $\mathrm{X}^{-}=\mathrm{BPh}_{4}^{-}$[81] or oxalate $[78,80]$ are irradiated into the OS CT band the formation of $\left[\mathrm{Co}^{\mathrm{II}}(\operatorname{sep})\right]^{2+}$ is observed since the anions are oxidized irreversibly. The photoreduction of aqueous $[\mathrm{Co}(\mathrm{sep})]^{3+}$ by oxalate can be used for the generation of $\mathrm{H}_{2}$ since in the presence of colloidal platinum $[\mathrm{Co}(\mathrm{sep})]^{2+}$ is able to reduce water. $[\mathrm{Co}(\mathrm{sep})]^{3+}$ sensitizes thus the reaction $[78,80]$ :

$$
\mathrm{H}_{2} \mathrm{C}_{2} \mathrm{O}_{4} \rightarrow 2 \mathrm{CO}_{2}+\mathrm{H}_{2}
$$

The organometallic ion pair $\left[\mathrm{Co}_{2}\left(\mathrm{C}_{10} \mathrm{H}_{8}\right)_{2}\right]^{2+} \mathrm{BPh}_{4}^{-}$represents a further interesting example of photoreactivity following OS donor to complex CT excitation [85]. The photolysis of the ion pair in $\mathrm{CH}_{3} \mathrm{CN}$ is associated with the reduction of the complex to $\left[\mathrm{Co}_{2}\left(\mathrm{C}_{10} \mathrm{H}_{8}\right)_{2}\right]^{+}$. Since this cation is stable product formation occurs only by the irreversible decay of the $\mathrm{BPh}_{4}$ radical.

\subsection{Neutral Acceptors and/or Donors}

As discussed in Sect. 3.2 the electronic spectra of reducing complexes dissolved in oxidizing solvents display frequently OS complex to solvent CT bands. Light absorption by such CT bands is associated with the oxidation of the complex. The solvent accepts the electrons either by an irreversible reduction (e.g. halo- 
genated alkanes) or by the formation of solvated electrons (e.g. $\mathrm{H}_{2} \mathrm{O}$ ) which can be intercepted by suitable scavengers such as $\mathrm{N}_{2} \mathrm{O}$. The complexes are then also irreversibly photooxidized. Anionic cyanide complexes such as $\left[\mathrm{Fe}(\mathrm{CN})_{6}\right]^{4-}$, $\left[\mathrm{Ru}(\mathrm{CN})_{6}\right]^{4-}$ or $\left[\mathrm{Mo}(\mathrm{CN})_{8}\right]^{4-}[89,90]$ and neutral organometallic complexes such as ferrocene $[91,92]$ have been used as electron donors. But also reducing cations such as $\left[\mathrm{Ru}\left(\mathrm{NH}_{3}\right)_{6}\right]^{2+}[118]$ and $\left[\mathrm{Co}_{2}\left(\mathrm{C}_{10} \mathrm{H}_{8}\right)_{2}\right]^{+}[85]$ are photooxidized upon OS complex to solvent CT excitation. Since this subject has been covered by several reviews $[8,19,33]$ it is not further discussed here.

To our knowledge there is not any other report on the photochemistry initiated by OS CT excitation not involving ion pairs or the solvent. Surely, such systems will be discovered in the future. For example, the green addition complexes formed between chloranil or tetracyanoethylene as acceptors and tricarbonyltoluenechromium as donor were reported to be photochemically unstable [94]. However, the nature of this light-sensitivity was not explored.

\section{Outlook and Conclusion}

Light-induced reactions which originate from OS CT excited states have been shown to play an important role in the field of photochemistry of coordination compounds. Since the majority of observations on this subject was reported only recently it is expected that many more examples of reactive OS CT states will be discovered in the near future. (After completion of this review an extensive publication on the spectroscopy and photochemistry of organometallic ions pairs was published by Bockman and Kochî [119]). We can anticipate the design of new photoactive OS CT systems for applications in industrial photochemistry. The observations on reactive OS CT states involving metal complexes are not only interesting in their own right, they are also an important supplement to the research on excited state electron transfer. Since optical OS CT is intimately related to thermal electron transfer our increasing knowledge on this subject will also contribute to a better understanding of the mechanism of thermal redox reactions.

\section{References}

1. Balzani V, Bolletta F, Gandolfi MT, Maestri M (1978) Top. Curr. Chem. 75: 1

2. Meyer TJ (1978) Acc. Chem. Res. 11: 94

3. Sutin N, Creutz C (1980) Pure Appl. Chem. 52: 2717

4. Meyer TJ (1983) Progr. Inorg. Chem. 30:389

5. Sutin N, Creutz C (1983) J. Chem. Ed. 60: 809

6. Serpone N (1988) In: Fox MA, Chanon M (eds) Photoinduced electron transfer. Elsevier, Amsterdam, part D, p 47

7. Balzani V, Scandola F (1988) In: Fox MA, Chanon M (eds) Photoinduced electron transfer. Elsevier, Amsterdam, part D, p 148

8. Gianotti C, Gaspard S, Kransz P (1988) In : Fox MA, Chanon M (eds) Photoinduced electron transfer. Elsevier, Amsterdam, part D, p 200 
9. Grätzel M (1988) In: Fox MA, Chanon M (eds) Photoinduced electron transfer. Elsevier, Amsterdam, part D, p 394

10. Meyer TJ (1989) Acc. Chem. Res. 22: 163

11. Grätzel M (1989) Heterogeneous photochemical electron transfer. CRC Press, Boca Raton

12. Vogler A, Osman AH, Kunkely H (1985) Coord. Chem. Rev. 64: 159

13. Hennig H, Rehorek D, Archer RD (1985) Coord. Chem. Rev. 61: 1

14. Balzani V, Sabbatini N, Scandola F (1986) Chem. Rev. 86: 319

15. Hennig H, Rehorek D, Billing R (1988) Comments Inorg. Chem. 8: 163

16. Stein CA, Taube H (1978) J. Am. Chem. Soc. 100: 1635

17. Vogler A (1988) In: Fox MA, Chanon M (eds) Photoinduced electron transfer. Elsevier, Amsterdam, part D, p 179

18. Lever ABP (1984) Inorganic electronic spectroscopy, Elsevier, Amsterdam

19. Geoffroy GL, Wrighton MS (1979) Organometallic photochemistry, Academic, New York

20. Taube H (1978) Ann. N.Y. Acad. Sci. 313: 483

21. Meyer TJ (1978) Ann. N.Y. Acad. Sci. 313: 496

22. Brown D (ed) (1980) Mixed-valence compounds, Reidel, Dordrecht

23. Creutz C (1980) Progr. Inorg. Chem. 30:1

24. Hush NS (1967) Progr. Inorg. Chem. 8: 391

25. Vogler A, Kunkely H (1989) Z. Naturforsch. 44b: 132

26. Vogler A, Kunkely H (1990) Comments Inorg. Chem. 9: 201

27. Hush NS (1961) Trans. Faraday Soc. 57: 557

28. Nush NS (1968) Electrochim. Acta 13: 1005

29. Powers MJ, Meyer TJ (1980) J. Am. Chem. Soc. 102: 1289

30. Hennig H, Billing R, Benedix R (1986) Monatshefte Chem. 117: 51

31. Hennig H, Benedix R, Billing R (1986) J. Prakt. Chem. 328: 829

32. Simic M, Lilie J (1974) J. Am. Chem. Soc. 96: 291

33. Fox M (1975) In: Adamson AW, Fleischauer PD (eds) Concepts of inorganic chemistry, Wiley, New York, p 333.

34. Jørgensen CK (1963) Acta Chem. Scand. 17: 1034

35. Vogler A, Kunkely H (1987) Inorg. Chem. 26: 1819

36. Vogler A, Kunkely H (1988) Inorg. Chim. Acta 144: 149

37. Vogler A, Kunkely H (1986) J. Chem. Soc. Chem. Commun.: 1616

38. Hennig H, Rehorek A, Ackermann M, Rehorek D, Thomas P (1983) Z. Anorg. Allg. Chem. 496: 186

39. Hennig H, Rehorek A, Rehorek D, Thomas P (1984) Inorg. Chim. Acta 86: 41

40. Haim A (1985) Comments Inorg. Chem. 4: 113

41. Vogler A, Kisslinger J (1982) Angew. Chem. Int. Ed. Engl. 21: 77

42. Osman AH (1987) Inter- und intramolekulare Photoredoxreaktionen von Übergangsmetallkomplexen. Thesis, Universität Regensburg, Regensburg

43. Vogler A, Kunkely H (1975) Ber. Bunsenges. Phys. Chem. 79: 83

44. Curtis JC, Meyer TJ (1978) J. Am. Chem. Soc. 100: 6284

45. Toma HE (1980) J. Chem. Soc. Dalton: 471

46. Curtis JC, Meyer TJ (1982) Inorg. Chem. $21: 1562$

47. Vogler A, Kisslinger J (1982) J. Am. Chem. Soc. 104: 2311

48. Sabbatini N, Bonazzi A, Ciano M, Balzani V (1984) J. Am. Chem. Soc. 106: 4055

49. Sabbatini N, Balzani V (1985) J] Less-Common Met. 112: 381

50. Vogler A, Kunkely H (1988) Inorg. Chim. Acta 150: 3

51. Lee KY, Kochi JK (1989) Inorg. Chem. 28: 567

52. Schramm C, Zink JI (1979) J. Am. Chem. Soc. 101: 4554

53. Hieber W, Vohler O, Braun G (1958) Z. Naturforsch. 13b: 192

54. Vogler A, Kunkely H (1988) Organometallics 7: 1449

55. Kruck T, Höfler M (1964) Chem. Ber. 97: 2289

56. Kruck T, Höfler M, Noack M (1966) Chem. Ber. 99: 1153

57. Fischer EO, Kögler HP (1956) Angew. Chem. 68: 462

58. Hieber W, Schropp W (1960) Chem. Ber. 93: 455

59. Bockman TM, Kochi JK (1988) J. Am. Chem. Soc. 110: 1294 
60. Kunkely H, Vogler A (1989) J. Organomet. Chem. 372: C29

61. Nakahara A, Wang JH (1963) J. Phys. Chem. 67: 496

62. Toma HE (1979) Can. J. Chem. 57: 2079

63. Curtis JC, Sullivan BP, Meyer TJ (1980) Inorg. Chem. 19: 3833

64. Rehorek D, Hantschmann A, Salvetter J, Hennig H (1979) J. Prakt. Chem. $328: 159$

65. Billing R, Rehorek D, Salvetter J, Hennig H (1988) Z. Anorg. Allg. Chem. 557: 234

66. Kisslinger J, Vogler A (unpublished results)

67. Borovnikov MS, Geosdovskij GN, Rybakov VA, Tarasov BP (1982) Zhurn. Obskh. Khim. $52: 331$

68. Calderazzo F, Pampaloni G, Lanfranchi M, Pelizzi G (1985) J. Organomet. Chem. 296: 1

69. Calderazzo F, Pampaloni G (1986) J. Organomet. Chem. 303: 111

70. Calderazzo F, Pampaloni G, Pelizzi G, Vitali F (1988) Organometallics 7: 1083.

71. Dance IG, Solstad PJ (1973) J. Am. Chem. Soc. 95: 7256

72. Fernandez A, Görner H, Kisch H (1985) Chem. Ber. 118: 1936

73. Lahner S, Wakatsuki Y, Kisch H (1987) Chem. Ber. 120: 1011

74. Megehee EG, Johnson CE, Eisenberg R (1989) Inorg. Chem. 28: 2423

75. Linhard M (1944) Z. Elektrochem. 50: 224

76. Linhard M, Weigel M (1951) Z. Anorg. Allg. Chem. 266: 49

77. Schmidtke H-H (1963) Z. Phys. Chem. N.F.: $38: 170$

78. Pina F, Ciano M, Mulazzani QG, Venturi M, Balzani V, Moggi L (1984) Sci. Papers I.P.C.R. $78: 166$

79. Pina F, Ciano M, Buggi L, Balzani V (1985) Inorg. Chem. 24: 844

80. Pina F, Mulazzani QG, Venturi M, Ciano M, Balzani V (1985) Inorg. Chem. 24: 848

81. Sugimoto H, Hataoka H, Mori M (1982) J. Chem. Soc. Chem. Commun.: 1301

82. Waysbort D, Evenor M, Navon G (1975) Inorg. Chem. 14: 514

83. Sexton DA, Curtis JC, Cohen H, Ford PC (1984) Inorg. Chem. $23: 49$

84. Elsbernd H, Beattie JK (1968) Inorg. Chem. 7: 2468

85. Clark SF, Watts RJ, Dubois DL, Connolly JS, Smart JC (1985) Coord. Chem. Rev. 64 : 273

86. Orgel LE (1954) Quarterly Rev. 8: 422

87. Harris CM, McKenzie ED (1963) J. Inorg. Nucl. Chem. 25: 171

88. Matsubara T, Efrima S, Metiu HT, Ford PC (1979) J. Chem. Soc. Faraday Trans II, $75: 390$

89. Kalisky O, Shirom M (1977) J. Photochem. 7: 215

90. Vogler A, Losse W, Kunkely H (1979) J. Chem. Soc. Chem. Commun.: 187

91. Brand JCD, Snedden W (1957) Trans. Faraday Soc. 53: 894

92. Traverso O, Scandola F (1970) Inorg. Chim. Acta 4: 493

93. Bock CR, Wrighton MS (1977) Inorg. Chem. 16: 1309

94. Fitch IW, Lagowski JJ (1966) J. Organomet. Chem. 5: 480

95. Huttner G, Fischer EO, Fischer RD, Carter OL, McPhail AT, Sim GA (1966) J. Organomet. Chem. $6: 288$

96. Huttner G, Fischer EO (1967) J. Organomet. Chem. 8: 299

97. Kobayashi H, Kobayashi M, Kaizu Y (1973) Bull. Chem. Soc. Jpn. 46: 3109

98. Kobayashi H, Kobayashi M, Kaizu Y (1975) Bull. Chem. Soc. Jpn 48: 1222

99. Holland GF, Mannig MC, Ellis DE, Trogler WC (1983) J. Am. Chem. Soc. 105: 2308

100. Lilie J, Shinohara N, Simic MG (1976) J. Am. Chem. Soc. $98: 6516$

101. Shinohara N, Lilie J, Simic MG (1977) Inorg. Chem. 16: 2809

102. Haim A, Wilmarth WK (1961) J. Am. Chem. Soc. 83: 509

103. Vogler A, Kunkely H (1975) Ber. Bunsenges. Phys. Chem. 79: 301

104. Vogler A, Osman AH, Kunkely H (1987) Inorg. Chem. 26: 2337

105. Larsson R (1967) Acta Chem. Scand. 21:257

106. Kane-Maguire NAP, Langford CH (1973) J. Chem. Soc. Chem. Commun.: 351

107. Langford CH, Sasseville RLP (1981) Can. J. Chem. 59: 647

108. Creutz C, Kroger P, Matsubara T, Netzel TL, Sutin N (1979) J. Am. Chem. Soc. $101: 5442$

109. Mirbach MF, Mirbach MJ, Wegman RW (1984) Organometallics 3: 900

110. McCleverty JA, Davison A, Wilkinson G (1965) J. Chem. Soc.: 3890

111. Meyer TJ, Caspar JV (1985) Chem. Rev. 85: 187 
Arnd Vogler and Horst Kunkely

112. Tyler DR (1988) Progr. Inorg. Chem. 36: 125

113. Doyle MP, Guy JK, Brown KC, Mahapatro SN, VanZyl CM, Pladziewicz JR (1987) J. Am. Chem. Soc. 109: 1536

114. Adamson AW, Sporer A (1958) J. Am. Chem. Soc. $80: 3865$

115. Rehorek D, Schmidt D, Hennig H (1980) Z. Chem. 20: 223

116. Hennig H, Walther D, Thomas P (1983) Z. Chem. $23: 446$

117. Nakashima M, Kida S (1982) Bull. Chem. Soc. Jpn. 55: 809

118. Matsubara T, Ford PC (1978) Inorg. Chem. 17: 1747

119. Bockman TM, Kochi JK (1989) J. Am. Chem. Soc. 111: 4669 